\begin{tabular}{|c|l|}
\hline Title & $\begin{array}{l}\text { Systematic structural control of multichromic platinum(II)-diimine complexes ranging from ionic solid to coordination } \\
\text { polymer }\end{array}$ \\
\hline Author(s) & Kobay ashi, A tsushi; Hara, Hirofumi; Y onemura, Tsubasa; Chang, Ho-Chol; Kato, Masako \\
\hline Citation & $\begin{array}{l}\text { Dalton Transactions, 41/6), 1878_1888 } \\
\text { https:/doi.org/40.1039/11t11155h }\end{array}$ \\
\hline Issue Date & 2012-02-14 \\
\hline Doc URL & http://hdl.handle.net/2115/50411 \\
\hline Rights & Dalton Trans., 2012, 41, 1878_1888- Reproduced by permission of The Royal Society of Chemistry (RSC) \\
\hline Type & article (author version) \\
\hline File Information & DT 41-6_1878-1888.pdf \\
\hline
\end{tabular}

Instructions for use 


\title{
Systematic structural control of multichromic platinum(II)-diimine complexes ranging from ionic solid to coordination polymer
}

\author{
Atsushi Kobayashi, ${ }^{* a}$ Hirofumi Hara, ${ }^{a}$ Tsubasa Yonemura, ${ }^{a}$ Ho-Chol Chang ${ }^{a}$ and Masako Kato ${ }^{* a}$ \\ Received (in XXX, XXX) Xth XXXXXXXXX 20XX, Accepted Xth XXXXXXXXX 20XX \\ ${ }_{5}$ DOI: 10.1039/b000000x
}

Reactions of a Pt(II)-diimine-based metalloligand $\mathrm{Na}_{2}\left[\mathrm{Pt}(\mathrm{CN})_{2}\left(4,4^{\prime}-\mathrm{dcbpy}\right)\right]\left(4,4^{\prime}-\mathrm{H}_{2} \mathrm{dcbpy}=4,4^{\prime}-\right.$ dicarboxy-2,2'-bipyridine) with alkaline-earth metal salts $\mathrm{Mg}\left(\mathrm{NO}_{3}\right)_{2} \cdot 6 \mathrm{H}_{2} \mathrm{O}, \mathrm{CaCl}_{2}, \mathrm{SrCl}_{2} \cdot 6 \mathrm{H}_{2} \mathrm{O}$, and $\mathrm{BaBr}_{2} \cdot 2 \mathrm{H}_{2} \mathrm{O}$ in aqueous solution gave luminescent complexes formulated as $\left[\mathrm{Mg}\left(\mathrm{H}_{2} \mathrm{O}\right)_{5}\right]\left[\mathrm{Pt}(\mathrm{CN})_{2}\left(4,44^{\prime}-\right.\right.$ dcbpy) $] \cdot 4 \mathrm{H}_{2} \mathrm{O}\left(\mathbf{M g P t}-\mathbf{4} \cdot 9 \mathrm{H}_{2} \mathrm{O}\right),\left\{\left[\mathrm{Ca}\left(\mathrm{H}_{2} \mathrm{O}\right)_{3}\right]\left[\mathrm{Pt}(\mathrm{CN})_{2}(4,4 '-\mathrm{dcbpy})\right] \cdot 3 \mathrm{H}_{2} \mathrm{O}\right\}_{\infty}\left(\mathbf{C a P t}-4 \cdot 6 \mathbf{H}_{2} \mathrm{O}\right)$,

$10\left\{\left[\mathrm{Sr}\left(\mathrm{H}_{2} \mathrm{O}\right)_{2}\right]\left[\mathrm{Pt}(\mathrm{CN})_{2}\left(4,4^{\prime}-\mathrm{dcbpy}\right)\right] \cdot \mathrm{H}_{2} \mathrm{O}\right\}_{\infty}\left(\mathbf{S r P t}-\mathbf{4} \cdot \mathbf{3} \mathbf{H}_{2} \mathbf{O}\right)$, and $\left\{\left[\mathrm{Ba}\left(\mathrm{H}_{2} \mathrm{O}\right)_{2}\right]\left[\mathrm{Pt}(\mathrm{CN})_{2}\left(4,4^{\prime}-\right.\right.\right.$

dcbpy) $\left.] \cdot 3 \mathrm{H}_{2} \mathrm{O}\right\}_{\infty}\left(\right.$ BaPt-4 $\left.\mathbf{5} \mathbf{H}_{2} \mathrm{O}\right)$, respectively. The crystal structures of all MPt-4 complexes were determined by X-ray crystallography. In these structures, the alkaline-earth metal ions are commonly coordinated to the carboxyl groups of the $\left[\mathrm{Pt}(\mathrm{CN})_{2}\left(4,4^{\prime}-\mathrm{dcbpy}\right)\right]^{2-}$ metalloligand. In the case of MgPt$\mathbf{4} \cdot 9 \mathrm{H}_{2} \mathrm{O}$, the $\mathrm{Mg}$ (II) ion is bound by five water molecules and one oxygen atom of a carboxyl group to 15 form a neutral complex molecule $\left[\mathrm{Mg}\left(\mathrm{H}_{2} \mathrm{O}\right)_{5}\right]\left[\mathrm{Pt}(\mathrm{CN})_{2}\left(4,4^{\prime}\right.\right.$-dcbpy) $]$. In contrast, the alkaline-earth metal ion and metalloligand form two-dimensional $\left(\mathrm{CaPt}-\mathbf{4} \cdot \mathbf{6} \mathbf{H}_{2} \mathrm{O}\right)$ and three-dimensional $\left(\mathbf{S r P t}-4 \cdot 3 \mathbf{H}_{2} \mathrm{O}\right.$ and BaPt-4.5 $\mathbf{H}_{2} \mathbf{O}$ ) coordination networks, respectively. All fully hydrated complexes exhibited a strong phosphorescence from the triplet $\pi-\pi^{*}$ transition state. Luminescence spectroscopy revealed that MgPt$\mathbf{4} \cdot \mathbf{9 H}_{2} \mathrm{O}$ exhibited interesting multichromic (i.e., thermo-, mechano-, and vapochromic) luminescence,

20 whereas $\mathbf{C a P t}-\mathbf{4} \cdot \mathbf{6} \mathbf{H}_{2} \mathbf{O}$ showed only thermochromic luminescence. The other two complexes did not exhibit any chromic behaviour. Combination analysis of powder X-ray diffraction, thermogravimetry, and IR spectroscopy suggests that the dimensionality of the coordination network contributes considerably to both the structural flexibility and luminescence properties; that is, the low-dimensional flexible coordination network formed in MPt-4 complexes with smaller alkaline-earth metal ions enables a ${ }_{25}$ structural rearrangement induced by thermal and mechanical stimuli and vapour adsorption, resulting in the observed multichromic behaviour.

\section{Introduction}

One-dimensionally stacked square-planer Pt(II) complexes have attracted considerable attention because of their characteristic 30 coloration, strong luminescence, and interesting chromic behaviours. ${ }^{1-6}$ In this system, the metallophilic interaction between the $\mathrm{Pt}(\mathrm{II})$ ions is known to play an important role in determining their unique physical properties. ${ }^{1-2}$ The overlap between the two $5 \mathrm{~d} z^{2}$ orbitals of the $\mathrm{Pt}(\mathrm{II})$ ions generates an 35 antibonding $\mathrm{d} \sigma^{*}$ orbital near the highest-occupied molecular orbital (HOMO) level. Because the energy of this $d \sigma^{*}$ orbital strongly depends on the distance between the $\mathrm{Pt}(\mathrm{II})$ ions, the colour and/or luminescence of the solid can be widely tuned by manipulating the $\mathrm{Pt}(\mathrm{II})-\mathrm{Pt}(\mathrm{II})$ distance. ${ }^{3-4}$ In 1995, Mann et al.

40 reported that intermolecular metallophilic interactions between $\mathrm{d}^{8}$ metal ions play a critical role in the vapochromic behaviour of these complexes. ${ }^{5}$ By exploiting these distance-dependent chromophoric properties, researchers have synthesized many vapochromic $\mathrm{Pt}(\mathrm{II})$ complexes. ${ }^{5-6}$ For example, Chen et al. 45 reported the unique vapochromic behaviour of a neutral $\mathrm{Pt}(\mathrm{II})$ complex $\left.\left[\mathrm{Pt}\left(\mathrm{Me}_{3} \mathrm{SiC} \equiv \mathrm{CbpyC} \equiv \mathrm{CSiMe}\right)_{3}\right)(\mathrm{PhC} \equiv \mathrm{C})_{2}\right]$ that varied the colour depending on the molecular weight of the hydrocarbons. ${ }^{60}$ In addition, some $\mathrm{Pt}(\mathrm{II})$ and $\mathrm{Au}(\mathrm{I})$ complexes have been recently found to exhibit interesting mechanochromic behaviour. ${ }^{7}$ 50 However, to the best of our knowledge, there are still few complexes that show the double-, triple-, and multichromic behaviours present in this Pt(II)-diimine series. ${ }^{7 \mathrm{~d}}$

We recently reported a chromic coordination polymer (CCP), $\left\{\left[\mathrm{Zn}\left(\mathrm{H}_{2} \mathrm{O}\right)_{3}\right]\left[\mathrm{Pt}(\mathrm{CN})_{2}\left(5,5^{\prime} \text {-dcbpy) }\right] \cdot \mathrm{H}_{2} \mathrm{O}\right\}_{n} \quad\left(\mathbf{Z n P t}-5 \cdot 4 \mathrm{H}_{2} \mathrm{O}\right)\right.$, built 55 from a $\mathrm{Zn}$ (II) ion and a $\mathrm{Pt}$ (II)-diimine-based metalloligand $\left[\mathrm{Pt}(\mathrm{CN})_{2}\left(5,5^{\prime}-\mathrm{H}_{2} \mathrm{dcbpy}\right)\right] \quad\left(5,5^{\prime}-\mathrm{H}_{2} \mathrm{dcbpy}=5,5^{\prime}\right.$-dicarboxy-2,2'bipyridine), ${ }^{8}$ because the structure of coordination polymer (CP) can be easily and widely modified by replacement of metal ions and bridging ligands. ${ }^{9-11}$ We found that the metallophilic 60 interaction between the $\mathrm{Pt}(\mathrm{II})$ atoms results in the metalloligands acting as chromic centres even within a relatively rigid coordination network, resulting in thermochromic and insoluble solvatochromic behaviours. In addition, the replacement of bridging metal ion from $\mathrm{Zn}^{2+}$ to alkaline-earth metal ions ${ }_{65}$ significantly affected both the vapour-adsorption property and solid-state solvatochromic behaviour. ${ }^{8 \mathrm{~b}}$ However, the one- 
dimensional coordination-network structure built from the alternate arrangement of $\mathrm{M}^{2+}$ ion and the metalloligand $\left[\mathrm{Pt}(\mathrm{CN})_{2}\left(5,5^{\prime}-\mathrm{dcbpy}\right)\right]^{2-}$ is commonly formed, resulting in the limitation of the structural control of the coordination-network 5 structure. Thus, in this work, to control both the chromotoropic behavior and coordination-network structure constructed by the $\mathrm{Pt}$ (II)-diimine-based metalloligand, we have synthesized four $\mathrm{Pt}$ (II)-diimine-based complexes using the isomeric metalloligand, $\left[\mathrm{Pt}(\mathrm{CN})_{2}\left(4,4^{\prime}-\mathrm{dcbpy}\right)\right]^{2-}$ with alkaline-earth metal ions, namely, $10\left[\mathrm{Mg}\left(\mathrm{H}_{2} \mathrm{O}\right)_{5}\right]\left[\mathrm{Pt}(\mathrm{CN})_{2}\left(4,4^{\prime}-\right.\right.$ dcbpy $\left.)\right] \cdot 4 \mathrm{H}_{2} \mathrm{O}$

$\left(\mathrm{MgPt}-4 \cdot 9 \mathrm{H}_{2} \mathrm{O}\right)$, $\left\{\left[\mathrm{Ca}\left(\mathrm{H}_{2} \mathrm{O}\right)_{3}\right]\left[\mathrm{Pt}(\mathrm{CN})_{2}\left(4,4^{\prime}-\mathrm{dcbpy}\right)\right] \cdot 3 \mathrm{H}_{2} \mathrm{O}\right\}_{\mathrm{n}} \quad\left(\mathbf{C a P t}-4 \cdot 6 \mathbf{H}_{2} \mathrm{O}\right)$, $\left\{\left[\mathrm{Sr}\left(\mathrm{H}_{2} \mathrm{O}\right)_{2}\right]\left[\mathrm{Pt}(\mathrm{CN})_{2}\left(4,4^{\prime}-\text { dcbpy }\right)\right] \cdot \mathrm{H}_{2} \mathrm{O}\right\}_{\mathrm{n}} \quad\left(\mathbf{S r P t}-\mathbf{4} \cdot \mathbf{3} \mathbf{H}_{2} \mathbf{O}\right)$, and $\left\{\left[\mathrm{Ba}\left(\mathrm{H}_{2} \mathrm{O}\right)_{2}\right]\left[\mathrm{Pt}(\mathrm{CN})_{2}\left(4,4^{\prime}-\mathrm{dcbpy}\right)\right] \cdot 3 \mathrm{H}_{2} \mathrm{O}\right\}_{\mathrm{n}} \quad\left(\mathbf{B a P t}-\mathbf{4} \cdot \mathbf{5} \mathbf{H}_{\mathbf{2}} \mathbf{O}\right) . \mathrm{We}$ found the position of the carboxyl group on the dcbpy ligand 15 significantly affected not only the crystal structures but also the luminescence properties and chromic behaviours, that is, the MgPt-4.9H $\mathrm{H}_{2} \mathrm{O}$ complex, without any infinite coordination network, showed interesting multichromic (thermo-, vapo-, and

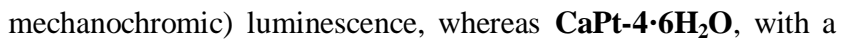
20 two-dimensional coordination-sheet structure, showed only thermochromic luminescence. The other two coordination polymers (CPs), which featured three-dimensional coordination networks, did not show any chromic behaviour. Although there are many chromic materials that use the $\mathrm{Pt}(\mathrm{II})$-diimine complexes 25 as chromophores, ${ }^{5-6} \mathbf{M g P t}-\mathbf{4} \cdot \mathbf{9} \mathrm{H}_{2} \mathrm{O}$ is a very rare example of a material that exhibits triple chromic behaviour. In this paper, we discuss the syntheses, crystal structures, and chromic behaviours of these Pt(II)-diimine-based MPt-4 $\boldsymbol{n} \mathbf{H}_{2} \mathbf{O}$ complexes on the basis of X-ray structural determinations, powder X-ray diffraction 30 measurements, and luminescence and IR spectroscopy.

\section{Experimental Section}

\section{Syntheses}

All starting materials, $\mathrm{K}_{2} \mathrm{PtCl}_{4}, \mathrm{Mg}\left(\mathrm{NO}_{3}\right)_{2} \cdot 6 \mathrm{H}_{2} \mathrm{O}, \mathrm{CaCl}_{2}$, $\mathrm{SrCl}_{2} \cdot 6 \mathrm{H}_{2} \mathrm{O}, \mathrm{BaBr}_{2} \cdot 2 \mathrm{H}_{2} \mathrm{O}$, and 3-methylpyridine were used as 35 received from commercial sources, and the solvents were used without any purification. Unless otherwise stated, all manipulations were performed in air. $\mathrm{Na}_{2}\left[\mathrm{Pt}(\mathrm{CN})_{2}\left(4,4^{\prime}-\right.\right.$ dcbpy) $] \cdot 2 \mathrm{H}_{2} \mathrm{O}$ was prepared according to a published method. ${ }^{6 p}$ Elemental analysis was performed at the analysis centre in ${ }_{40}$ Hokkaido University.

Synthesis of $\left[\mathrm{Mg}\left(\mathrm{H}_{2} \mathrm{O}\right)_{5}\right]\left[\mathrm{Pt}(\mathrm{CN})_{2}\left(4,4^{\prime}\right.\right.$-dcbpy) $] \cdot 4 \mathrm{H}_{2} \mathrm{O}$ (MgPt4.9H $\left.\mathrm{H}_{2} \mathrm{O}\right): \mathrm{Na}_{2}\left[\mathrm{Pt}(\mathrm{CN})_{2}\left(4,4^{\prime}-\mathrm{dcbpy}\right)\right] \cdot 2 \mathrm{H}_{2} \mathrm{O}(10 \mathrm{mg}, 17 \mu \mathrm{mol})$ was dissolved in water $(0.5 \mathrm{ml})$. To this clear pale-yellow solution, an aqueous solution $(0.5 \mathrm{ml})$ of $\mathrm{Mg}\left(\mathrm{NO}_{3}\right)_{2} \cdot 6 \mathrm{H}_{2} \mathrm{O}(5.3 \mathrm{mg}, 20 \mu \mathrm{mol})$

45 was added, resulting in the gradual emergence of an orange precipitate. After standing at room temperature for 3 days, the orange precipitate changed to pale-yellow platelet crystals. The crystals were collected by filtration and washed with a small amount of water and then dried in air for 1 day to afford MgPt${ }_{50} 4.9 \mathrm{H}_{2} \mathrm{O}(6.9 \mathrm{mg})$ in a $59 \%$ yield. One of the single crystals was used for X-ray structural determination. Elemental analysis for $\mathrm{C}_{14} \mathrm{H}_{6} \mathrm{~N}_{4} \mathrm{O}_{4} \mathrm{PtMg} \cdot 9 \mathrm{H}_{2} \mathrm{O}$; calcd.: C 24.88, H 3.58, N 8.29; found: $\mathrm{C}$ 24.41, H 3.39, N 8.35. IR $\left(\mathrm{KBr}, \mathrm{cm}^{-1}\right): 3391 \mathrm{~s}, 2159 \mathrm{~s}, 2148 \mathrm{~s}$, 1606 s, 1552 s, 1434 w, 1411 w, 1382 s, 1302 w, 1277 w, 1245 m, 551159 w, 1108 w, 1072 m, 1038 w, 920 w, 877 w, 788 m, 708 m, $475 \mathrm{w}$.

Synthesis of $\left\{\left[\mathrm{Ca}\left(\mathrm{H}_{2} \mathrm{O}\right)_{3}\right]\left[\mathrm{Pt}(\mathrm{CN})_{2}\left(4,4^{\prime} \text {-dcbpy) }\right] \cdot 3 \mathrm{H}_{2} \mathrm{O}\right\}_{\mathrm{n}}(\mathrm{CaPt}-\right.$ 4. $\left.6 \mathrm{H}_{2} \mathrm{O}\right): \mathrm{Na}_{2}\left[\mathrm{Pt}(\mathrm{CN})_{2}\left(4,4^{\prime}-\mathrm{dcbpy}\right)\right] \cdot 2 \mathrm{H}_{2} \mathrm{O}(10 \mathrm{mg}, 17 \mu \mathrm{mol})$ was dissolved in water $(0.5 \mathrm{ml})$. To this clear pale-yellow solution, an
60 aqueous solution $(0.5 \mathrm{ml})$ of $\mathrm{CaCl}_{2}(2.4 \mathrm{mg}, 21 \mu \mathrm{mol})$ was added resulting in the gradual emergence of an orange precipitate. After standing at room temperature for 2 weeks, the orange precipitate changed slowly to pale-yellow needle-like crystals. The crystals were collected by filtration and washed with a small amount of 65 water and then dried in air for 1 day to afford $\mathbf{C a P t}-4 \cdot \mathbf{6 H}_{2} \mathrm{O}(4.2$ $\mathrm{mg}$ ) in a $39 \%$ yield. One of the single crystals was used for X-ray structural determination. Elemental analysis for $\mathrm{C}_{14} \mathrm{H}_{6} \mathrm{~N}_{4} \mathrm{O}_{4} \mathrm{PtCa} \cdot 6 \mathrm{H}_{2} \mathrm{O}$; calcd.: C 26.38, $\mathrm{H} 2.85$, N 8.79; found: $\mathrm{C}$ 26.10, H 2.88, N 8.47. IR (KBr, cm $\left.{ }^{-1}\right): 3404 \mathrm{~s}, 3074 \mathrm{w}, 2160 \mathrm{~s}$, $702143 \mathrm{~s}, 1603 \mathrm{~s}, 1550 \mathrm{~s}, 1445 \mathrm{~m}, 1418 \mathrm{~s}, 1392 \mathrm{~s}, 1291 \mathrm{w}, 1244 \mathrm{~m}$, 1164 w, 1115 w, 1070 w, 1040 w, 924 w, 872 w, 798 w, 787 m, $716 \mathrm{~m}, 475 \mathrm{w}$.

Synthesis of $\left\{\left[\operatorname{Sr}\left(\mathrm{H}_{2} \mathrm{O}\right)_{2}\right]\left[\mathrm{Pt}(\mathrm{CN})_{2}\left(4,4^{\prime} \text {-dcbpy) }\right] \cdot \mathrm{H}_{2} \mathrm{O}\right\}_{\mathrm{n}}\right.$ (SrPt4-3 $\left.\mathrm{H}_{2} \mathrm{O}\right): \mathrm{Na}_{2}\left[\mathrm{Pt}(\mathrm{CN})_{2}\left(4,4^{\prime}-\mathrm{dcbpy}\right)\right] \cdot 2 \mathrm{H}_{2} \mathrm{O}(20 \mathrm{mg}, 35 \mu \mathrm{mol})$ was 75 dissolved in water $(2 \mathrm{ml})$. To this clear pale-yellow solution, an aqueous solution $(1 \mathrm{ml})$ of $\mathrm{SrCl}_{2} \cdot 6 \mathrm{H}_{2} \mathrm{O}(9.5 \mathrm{mg}, 35.6 \mu \mathrm{mol})$ was added resulting in the rapid precipitation of a pale-yellow solid. After stirring for $1 \mathrm{~h}$ at room temperature, the precipitate was collected by filtration and washed with a small amount of water 80 and then dried in air for 1 day to afford SrPt-4.3H $\mathbf{3} \mathbf{O}(19 \mathrm{mg})$ in an $86 \%$ yield. Pale-yellow single crystals suitable for X-ray crystallographic analysis were obtained by the diffusion of a $\mathrm{SrCl}_{2}$ ethanol solution into an aqueous solution of $\mathrm{Na}_{2}\left[\mathrm{Pt}(\mathrm{CN})_{2}(4,4\right.$ '-dcbpy) $] \cdot 2 \mathrm{H}_{2} \mathrm{O}$. Elemental analysis for ${ }_{85} \mathrm{C}_{14} \mathrm{H}_{6} \mathrm{~N}_{4} \mathrm{O}_{4} \mathrm{PtSr} \cdot 3 \mathrm{H}_{2} \mathrm{O}$; calcd.: C 26.65, H 1.92, N 8.88; found: $\mathrm{C}$ 26.71, H 1.78, N 8.74. IR ( $\left.\mathrm{KBr}, \mathrm{cm}^{-1}\right): 3433 \mathrm{~s}, 3080 \mathrm{w}, 2165 \mathrm{~s}$, $2145 \mathrm{~s}, 1620 \mathrm{~s}, 1589 \mathrm{~s}, 1551 \mathrm{~s}, 1448 \mathrm{~m}, 1413 \mathrm{~s}, 1384 \mathrm{~s}, 1307 \mathrm{w}$, 1284 w, 1244 m, 1169 w, 1109 w, 1069 w, 1039 w, 918 w, 864 m, $810 \mathrm{w}, 798 \mathrm{w}, 785 \mathrm{~m}, 774 \mathrm{w}, 713 \mathrm{~m}, 476 \mathrm{w}$.

${ }_{90}$ Synthesis of $\left\{\left[\mathrm{Ba}\left(\mathrm{H}_{2} \mathrm{O}\right)_{2}\right]\left[\mathrm{Pt}(\mathrm{CN})_{2}\left(4,4^{\prime} \text {-dcbpy) }\right] \cdot 3 \mathrm{H}_{2} \mathrm{O}\right\}_{\mathbf{n}}\right.$ (BaPt4.5 $\left.\mathbf{H}_{2} \mathbf{O}\right): \mathrm{Na}_{2}\left[\mathrm{Pt}(\mathrm{CN})_{2}\left(4,4^{\prime}-\mathrm{dcbpy}\right)\right] \cdot 2 \mathrm{H}_{2} \mathrm{O}(20 \mathrm{mg}, 35 \mu \mathrm{mol})$ was dissolved in water $(2 \mathrm{ml})$. To this clear pale-yellow solution, an aqueous solution $(1 \mathrm{ml})$ of $\mathrm{BaBr}_{2} \cdot 2 \mathrm{H}_{2} \mathrm{O}(12 \mathrm{mg}, 36 \mu \mathrm{mol})$ was added resulting in the rapid precipitation of a pale-yellow solid.

${ }_{95}$ After subsequent stirring for $1 \mathrm{~h}$ at room temperature, the precipitate was collected by filtration and washed with a small amount of water and then dried in air for 1 day to afford BaPt$\mathbf{4} \cdot \mathbf{5} \mathbf{H}_{2} \mathrm{O}(21 \mathrm{mg})$ in an $84 \%$ yield. Pale-yellow single crystals suitable for X-ray crystallographic analysis were obtained by the 100 diffusion of $\mathrm{a} \mathrm{BaBr}_{2}$ ethanol solution into an aqueous solution of $\mathrm{Na}_{2}\left[\mathrm{Pt}(\mathrm{CN})_{2}\left(4,4^{\prime}\right.\right.$-dcbpy) $] \cdot 2 \mathrm{H}_{2} \mathrm{O}$. Elemental analysis for $\mathrm{C}_{14} \mathrm{H}_{6} \mathrm{~N}_{4} \mathrm{O}_{4} \mathrm{PtBa} \cdot 5 \mathrm{H}_{2} \mathrm{O}$; calcd.: C 23.46, H 2.25, N 7.82; found: $\mathrm{C}$ 23.18, H 2.19, N 7.63. IR ( KBr, cm $\left.\mathrm{cm}^{-1}\right): 3422 \mathrm{~s}, 3078 \mathrm{w}, 2157 \mathrm{~s}$, $2146 \mathrm{~s}, 1617 \mathrm{~s}, 1583 \mathrm{~s}, 1550 \mathrm{~s}, 1438 \mathrm{w}(\mathrm{sh}), 1411 \mathrm{w}(\mathrm{sh}), 1384 \mathrm{~s}$, 1051287 w, 1243 m, 1106 w, 1071 w, 1038 w, 918 w, 861 w, 785 m, $709 \mathrm{~m}, 478 \mathrm{w}$.

\section{Single-crystal X-ray structural determination.}

All single-crystal X-ray diffraction measurements were performed using a Rigaku Mercury CCD diffractometer with 110 graphite monochromated Mo K $\alpha$ radiation $(\lambda=0.71069 \AA)$ and a rotating anode generator. Each single crystal was mounted on a MicroMount with paraffin oil. A nitrogen gas flow temperature controller was used to cool the sample. Diffraction data were collected and processed using CrystalClear. ${ }^{12}$ The structure was 115 solved by a direct method using SIR2004, ${ }^{13}$ and refined by fullmatrix least squares using SHELXL-97. ${ }^{14}$ The non-hydrogen atoms in MgPt-4.9H $\mathrm{H}_{2} \mathrm{O}$, CaPt-4.6 $\mathrm{H}_{2} \mathrm{O}$ and BaPt-4.5 $\mathrm{H}_{2} \mathrm{O}$ were refined anisotropically. In the case of $\mathbf{S r P t}-\mathbf{4} \cdot \mathbf{3 H}_{2} \mathrm{O}$, the carbon and nitrogen atoms of the bipyridine rings were refined 20 isotropically and the other non-hydrogen atoms were refined anisotropically due to the poor crystallinity. Disordered water molecules in CaPt-4.6 $\mathrm{H}_{2} \mathrm{O}$ were taken into account using PLATON/SQUEEZE. ${ }^{15}$ Hydrogen atoms were refined using the 
riding model. All calculations were performed using the Crystal Structure crystallographic software package. ${ }^{16}$ The obtained crystallographic data for each complex are summarized in Table 1.

Table 1 Crystal parameters and refinement data.

\begin{tabular}{|c|c|c|c|c|}
\hline Complex & MgPt-4.9H & $\mathrm{CaPt}-4 \cdot 6 \mathrm{H}_{2} \mathrm{O}$ & SrPt-4.3H $\mathrm{H}_{2} \mathrm{O}$ & BaPt-4.5 $\mathrm{H}_{2} \mathrm{O}$ \\
\hline$T / \mathrm{K}$ & $173(1)$ & $150(1)$ & $150(1)$ & $150(1)$ \\
\hline Formula & $\begin{array}{c}\mathrm{C}_{14} \mathrm{H}_{6} \mathrm{~N}_{4} \mathrm{O}_{4} \mathrm{Pt} \\
\mathrm{Mg} \cdot 9 \mathrm{H}_{2} \mathrm{O}\end{array}$ & $\begin{array}{c}\mathrm{C}_{14} \mathrm{H}_{6} \mathrm{~N}_{4} \mathrm{O}_{4} \mathrm{Pt} \\
\mathrm{Ca} \cdot 6 \mathrm{H}_{2} \mathrm{O}\end{array}$ & $\begin{array}{c}\mathrm{C}_{14} \mathrm{H}_{6} \mathrm{~N}_{4} \mathrm{O}_{4} \mathrm{Pt} \\
\mathrm{Sr} \cdot 3 \mathrm{H}_{2} \mathrm{O}\end{array}$ & $\begin{array}{c}\mathrm{C}_{14} \mathrm{H}_{6} \mathrm{BaN}_{4} \mathrm{O}_{4} \\
\mathrm{Pt} \cdot 5 \mathrm{H}_{2} \mathrm{O}\end{array}$ \\
\hline $\begin{array}{l}\text { Formula } \\
\text { weight }\end{array}$ & 675.76 & 637.49 & 630.98 & 716.72 \\
\hline $\begin{array}{l}\text { Crystal } \\
\text { system }\end{array}$ & Triclinic & Monoclinic & Triclinic & Monoclinic \\
\hline Space group & $P-1$ & $P 2_{1} / n$ & $P-1$ & $P 2_{1} / n$ \\
\hline$a / \AA$ & $6.924(4)$ & $7.1293(19)$ & $7.072(2)$ & $7.3068(19)$ \\
\hline$b / \AA$ & $13.689(8)$ & $17.848(4)$ & $10.385(4)$ & $17.634(5)$ \\
\hline$c / \AA$ & $13.933(7)$ & $16.168(4)$ & $12.842(4)$ & $15.226(4)$ \\
\hline$\alpha /^{\circ}$ & $114.208(5)$ & 90 & $100.695(6)$ & 90 \\
\hline$\beta 1^{\circ}$ & $95.815(4)$ & $96.7810(14)$ & $91.181(6)$ & $94.4477(11)$ \\
\hline$\gamma 1^{\circ}$ & $104.400(4)$ & 90 & $94.614(6)$ & 90 \\
\hline$V / \AA^{3}$ & $1135.4(10)$ & $2043.0(9)$ & $923.2(5)$ & $1955.9(9)$ \\
\hline $\mathrm{Z}$ & 2 & 4 & 2 & 4 \\
\hline$D_{\text {cal }} / / \mathrm{g} \cdot \mathrm{cm}^{-3}$ & 1.977 & 2.080 & 2.270 & 2.434 \\
\hline $\begin{array}{l}\text { Reflections } \\
\text { collected }\end{array}$ & 9040 & 16257 & 7348 & 15324 \\
\hline $\begin{array}{l}\text { Unique } \\
\text { reflections }\end{array}$ & 5085 & 4675 & 4062 & 4476 \\
\hline GOF & 1.104 & 1.004 & 0.965 & 1.061 \\
\hline$R_{\text {int }}$ & 0.040 & 0.070 & 0.047 & 0.052 \\
\hline $\begin{array}{c}R(\mathrm{I}> \\
2.00 \sigma(\mathrm{I}))\end{array}$ & 0.0518 & 0.0335 & 0.0693 & 0.0393 \\
\hline$R_{W}{ }^{a}$ & 0.1549 & 0.0826 & 0.1907 & 0.0839 \\
\hline \multicolumn{5}{|c|}{${ }^{a} R_{W}=\left[\Sigma\left(\mathrm{w}\left(\mathrm{F}_{\mathrm{o}}^{2}-\mathrm{F}_{\mathrm{c}}{ }^{2}\right)^{2}\right) / \Sigma \mathrm{w}\left(\mathrm{F}_{\mathrm{o}}{ }^{2}\right]^{2}\right]^{1 / 2}$} \\
\hline
\end{tabular}

\section{Powder X-ray diffraction.}

Powder X-ray diffraction (PXRD) measurements at various temperatures were performed using a Rigaku SPD diffractometer at beamline BL-8B at the Photon Factory, KEK, Japan. The 10 wavelength of the synchrotron X-ray was $1.200(1) \AA$ A. The sample was placed in a glass capillary with a $0.5-\mathrm{mm}$ diameter. The temperature of the sample was controlled using a nitrogen gas flow variable temperature controller.

\section{Luminescence spectroscopy.}

15 Luminescence spectra were recorded under various conditions on a Jasco FP-6600 spectrofluorometer. The sample temperature was controlled by a JASCO ETC-273 Peltier-type temperature controller. About $1 \mathrm{mg}$ of the sample was placed in a glass capillary with a $0.5-\mathrm{mm}$ diameter. The slit widths of the 20 excitation and emission light were 5 and $6 \mathrm{~nm}$, respectively.

\section{Luminescence quantum efficiency measurements.}

The luminescence quantum efficiency of each sample in the solid state was recorded using a Hamamatsu C9920-02 absolute photoluminescence quantum yield measurement system equipped 25 with an integrating sphere apparatus and a $150 \mathrm{~W}$ CW Xenon light source.

\section{Luminescence lifetimes.}

The luminescence lifetime of each sample was recorded using a Hamamatsu C4780 Picosecond Fluorescence Lifetime 30 Measurement System equipped with a nitrogen laser light source $(\lambda=337.1 \mathrm{~nm})$

\section{Thermogravimetric analysis.}

Thermogravimetry and differential thermal analysis were performed using a Rigaku ThermoEvo TG8120 analyzer.

\section{${ }_{35}$ IR spectroscopy.}

The IR spectrum of each complex was recorded on a Nicolet 6700 FT-IR spectrometer equipped with a Smart-Orbit (Diamond) ATR accessory.

\section{Results and discussion}

\section{${ }_{40}$ Crystal structures.}

Figure 1(a) shows the molecular structure of MgPt-4-9H2O. The complex crystallized in the triclinic $P-1$ space group. The $\mathrm{Mg}$ (II) ion is surrounded by one carboxyl oxygen of the $\left[\mathrm{Pt}(\mathrm{CN})_{2}\left(4,4^{\prime}-\right.\right.$ dcbpy) $]^{2-}$ metalloligand and five water molecules to form a 45 neutral molecule, $\left\{\left[\mathrm{Mg}\left(\mathrm{H}_{2} \mathrm{O}\right)_{5}\right]\left[\mathrm{Pt}(\mathrm{CN})_{2}\left(4,4^{\prime}-\right.\right.\right.$ dcbpy $\left.\left.)\right]\right\}$. The average $\mathrm{Mg}-\mathrm{O}$ (water) bond distances ranged from 2.06-2.09 $\AA$, which is consistent with the oxygen atoms originating from water molecules as opposed to anionic hydroxide ions. In the $\left[\mathrm{Pt}(\mathrm{CN})_{2}\left(4,4^{\prime}-\text { dcbpy }\right)\right]^{2-}$ moiety, all atoms except for the carboxyl 50 oxygens lie on the $\mathrm{PtC}_{2} \mathrm{~N}_{2}$ coordination plane. The bond lengths and angles around the metalloligand are very similar to those in the sodium salt, $\mathrm{Na}_{2}\left[\mathrm{Pt}(\mathrm{CN})_{2}\left(4,4^{\prime}-\mathrm{dcbpy}\right)\right] \cdot 5 \mathrm{H}_{2} \mathrm{O}$ (see Table $\mathrm{S} 1$ in supporting information). In the case of the protonated complex $\left[\mathrm{Pt}(\mathrm{CN})_{2}\left(4,4^{\prime}-\mathrm{H}_{2} \mathrm{dcbpy}\right)\right]$, the $\mathrm{Pt}(\mathrm{II})$ ions formed a one-
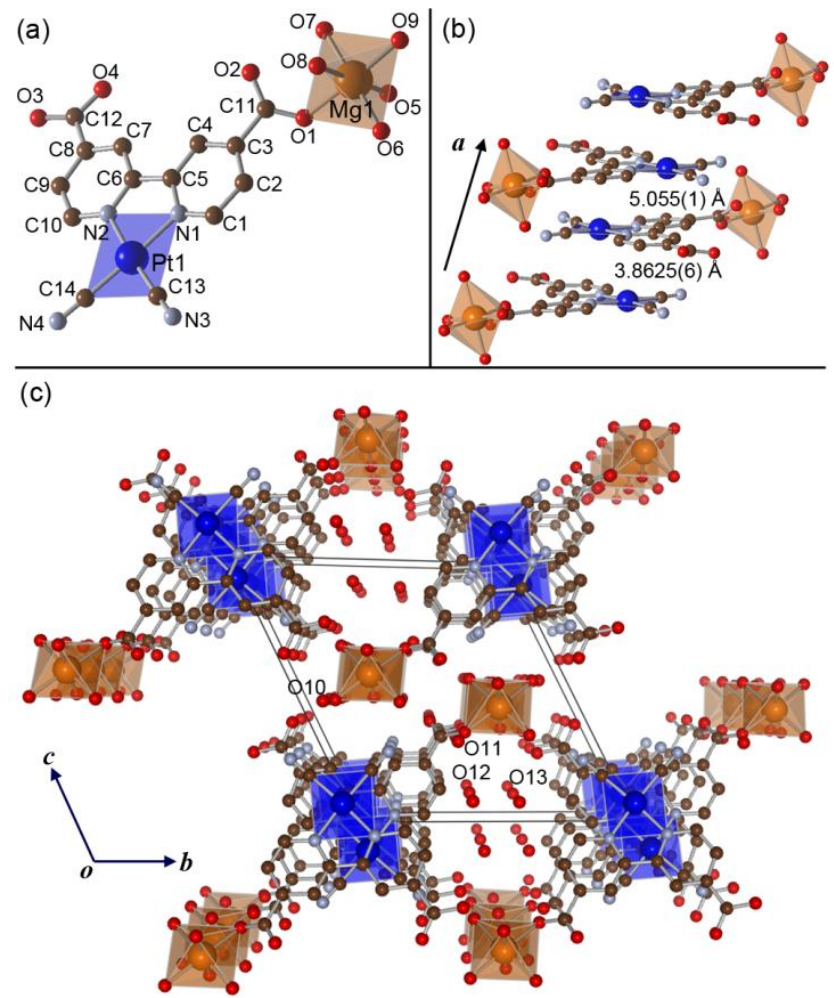

55

Fig. 1 (a) Molecular structure, (b) 1-D stacked structure, and (c) packing diagram viewed down along the $a$ axis of $\mathbf{M g P t}-4 \cdot 9 \mathbf{H}_{2} \mathrm{O}$. The coordination spheres of the $\mathrm{Pt}(\mathrm{II})$ and $\mathrm{Mg}$ (II) ions are shown as blue planes and orange octahedrons, respectively. $\mathrm{H}$ atoms are omitted for 60 clarity. Solvated water molecules are omitted in (a) and (b) for clarity. The brown, light-blue, and red spheres represent $\mathrm{C}, \mathrm{N}$, and $\mathrm{O}$ atoms, respectively. ${ }^{18}$ 
(a)
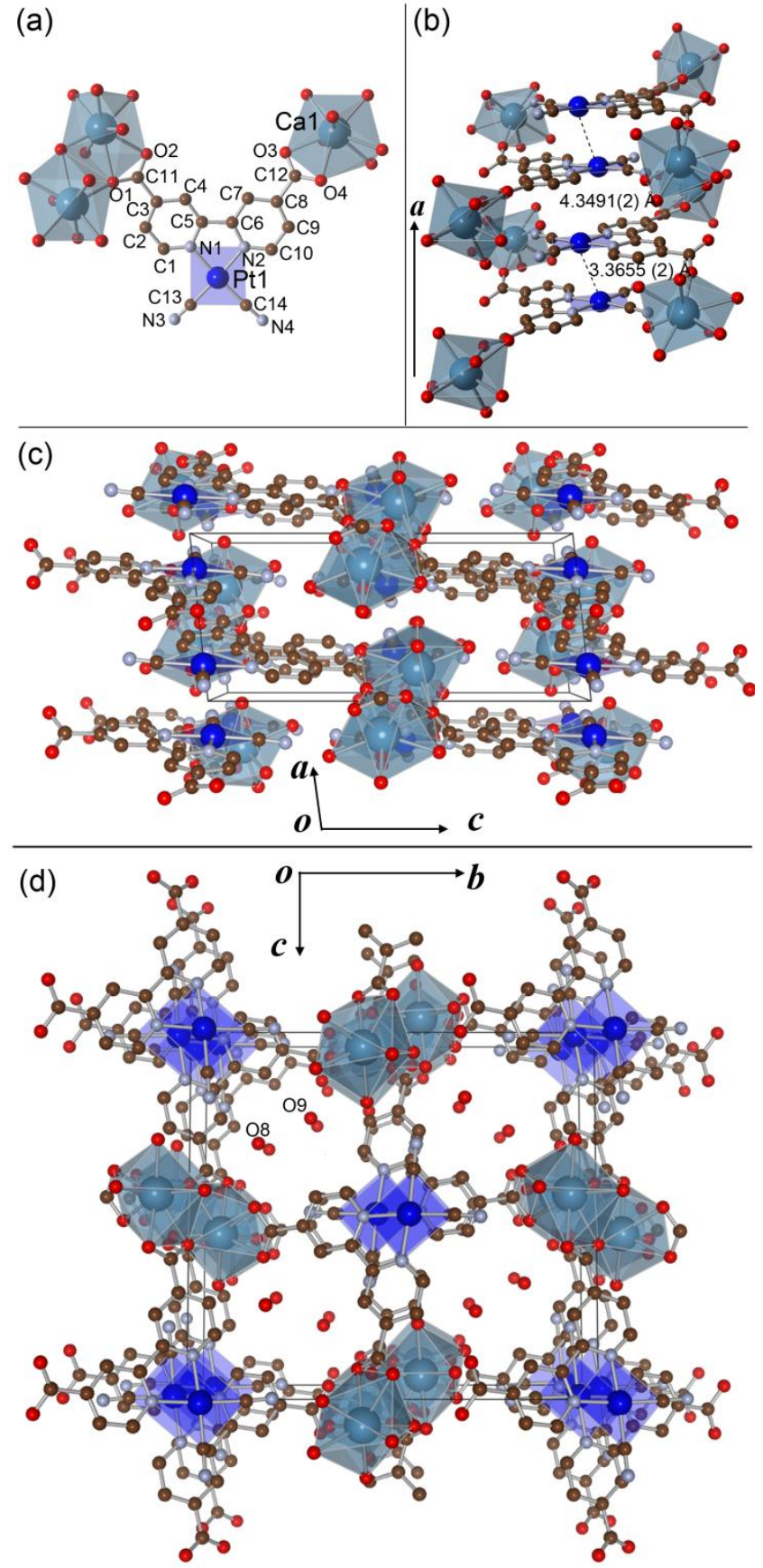

Fig. 2 (a) Asymmetric unit, (b) 1-D stacked structure, and (c) packing diagrams viewed down along the $b$ and (d) $a$ axes of $\mathbf{C a P t}-4 \cdot 6 \mathbf{H}_{2} \mathbf{O}$. The coordination spheres of the $\mathrm{Pt}(\mathrm{II})$ and $\mathrm{Ca}(\mathrm{II})$ ions are shown as blue

5 planes and grayish blue polyhedrons, respectively. The dotted lines represent the effective metallophilic interaction between $\mathrm{Pt}(\mathrm{II})$ ions. $\mathrm{H}$ atoms are omitted for clarity. Solvated water molecules are omitted in (a), (b), and (c) for clarity. Brown, light-blue, and red spheres represent C, N, and $\mathrm{O}$ atoms, respectively. ${ }^{18}$

10 dimensional (1-D) column with effective metallophilic interaction at a distance of $3.3 \AA^{.6 h}$ In contrast, the Pt(II) ions in MgPt$\mathbf{4} \cdot 9 \mathrm{H}_{2} \mathrm{O}$ form a zigzag-type chain structure, as shown in Figure 1(b), and even the shortest distance between neighboring Pt(II) ions is over $3.7 \AA$. This result indicates that the metallophilic 15 interaction between the $\mathrm{Pt}(\mathrm{II})$ ions in $\mathbf{M g P t}-\mathbf{4} \cdot \mathbf{9} \mathbf{H}_{\mathbf{2}} \mathbf{O}$ is negligibly weak. It should be noted that there are nine water molecules in (a)

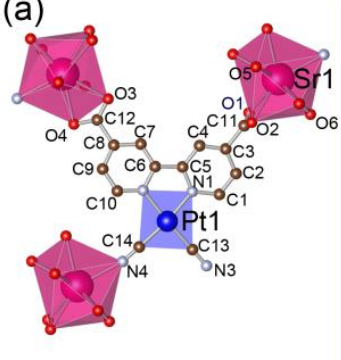

(b)
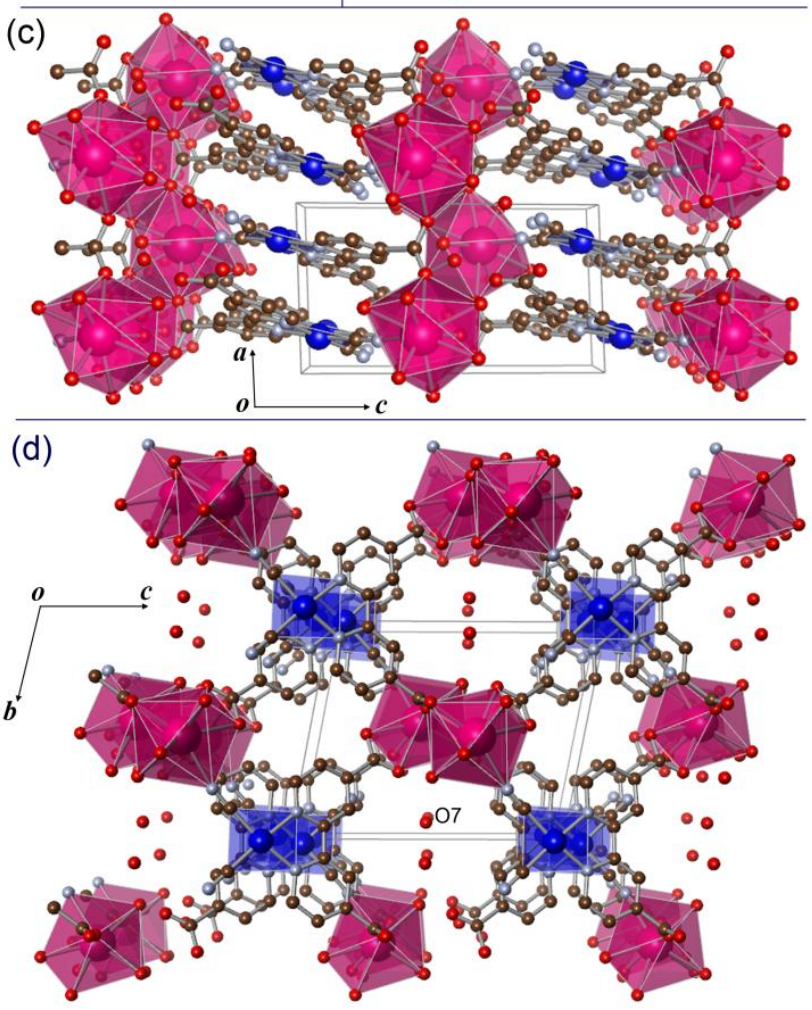

Fig. 3 (a) Asymmetric unit, (b) 1-D stacked structure, and (c) packing diagrams viewed down along the $b$ and (d) $a$ axes of SrPt-4 $\mathbf{3} \mathbf{H}_{2} \mathbf{O}$. The 20 coordination spheres of the $\mathrm{Pt}(\mathrm{II})$ and $\mathrm{Sr}(\mathrm{II})$ ions are shown as blue planes and purple polyhedrons, respectively. The dotted lines represent the effective metallophilic interaction between $\mathrm{Pt}(\mathrm{II})$ ions. $\mathrm{H}$ atoms are omitted for clarity. Solvated water molecules are omitted in (a), (b), and (c) for clarity. Brown, light-blue, and red spheres represent $\mathrm{C}, \mathrm{N}$, and $\mathrm{O}$ atoms, respectively. ${ }^{18}$

one unit cell, i.e., five coordinated to the $\operatorname{Mg}(\mathrm{II})$ ion and four crystal water molecules. Two of the four crystal water molecules (O10 and O11) are tightly bound by four hydrogen bonds. In contrast, the other two water molecules (O12 and O13) form only 30 one hydrogen bond to the tightly bound crystal water, resulting in larger temperature factors. The latter water molecules form a water channel along the $a$ axis, as shown in Figure 1(c).

Figure 2(a) shows the structure of $\mathbf{C a P t}-4 \cdot 6 \mathrm{H}_{2} \mathrm{O}$ in one asymmetric unit. The complex $\mathbf{C a P t}-\mathbf{4} \cdot \mathbf{6} \mathbf{H}_{\mathbf{2}} \mathrm{O}$ crystallized in the 35 monoclinic $P 2_{1} / n$ space group. Only one crystallographically independent $\mathrm{Ca}$ (II) ion and the $\left[\mathrm{Pt}(\mathrm{CN})_{2}\left(4,4^{\prime}-\mathrm{dcbpy}\right)\right]^{2-}$ metalloligand were found in the unit cell. The $\mathrm{Ca}(\mathrm{II})$ ion is surrounded by five carboxyl oxygen atoms and three water molecules, resulting in an eight-coordinate structure. The ${ }_{40}$ metalloligand $\left[\mathrm{Pt}(\mathrm{CN})_{2}\left(4,4^{\prime}-\mathrm{dcbpy}\right)\right]^{2-}$ is bound to three $\mathrm{Ca}(\mathrm{II})$ ions, as shown in Figure 2(a). The oxygen atoms from one of the 
two carboxyl groups (O3 and $\mathrm{O} 4)$ are bound to a $\mathrm{Ca}$ ion in a bidentate fashion. The oxygen atoms of another carboxyl group (O1 and $\mathrm{O} 2$ ) are also coordinated to the $\mathrm{Ca}$ ion in a bidentate fashion, but the $\mathrm{O} 1$ atom also bridges to the adjacent $\mathrm{Ca}$ ion 5 (Figure 2(a)). The $\left[\operatorname{Pt}(\mathrm{CN})_{2}\left(4,4^{\prime}-d c b p y\right)\right]^{2-}$ units stack with a zigzag-type chain arrangement along the $a$ axis, as shown in Figure 2(b). Owing to an effective metallophilic interaction between the $\mathrm{Pt}(\mathrm{II})$ ions, the $\left[\mathrm{Pt}(\mathrm{CN})_{2}\left(4,4^{\prime}-\mathrm{dcbpy}\right)\right]^{2-}$ units are moderately dimerized, with the shortest adjacent Pt-Pt distance 10 being 3.3655(2) $\AA$ (Figure 2(b)). As a result of the crosslink of the $\mathrm{Ca}$ ions by the metalloligands, an infinite two-dimensional coordination-bonded sheet is formed on the (101) plane, as shown in Figure 2(c). Three coordinated water molecules and two crystal water molecules were found in one unit cell. These crystal water 15 molecules form 1-D water channels along the $a$ axis, as shown in Figure 2(d).

Figure 3(a) shows the structure of $\mathbf{S r P t}-\mathbf{4} \cdot \mathbf{3} \mathrm{H}_{2} \mathrm{O}$ in one asymmetric unit. The complex $\mathbf{S r P t}-\mathbf{4} \cdot \mathbf{3} \mathbf{H}_{\mathbf{2}} \mathbf{O}$ crystallized in the triclinic $P-1$ space group. Similar to $\mathbf{C a P t}-4 \cdot \mathbf{6 H}_{2} \mathbf{O}$, only one 20 crystallographically independent $\operatorname{Sr}(\mathrm{II})$ ion and $\left[\mathrm{Pt}(\mathrm{CN})_{2}\left(4,4^{\prime}-\right.\right.$ dcbpy) $]^{2-}$ were found in the unit cell. The $\mathrm{Sr}(\mathrm{II})$ ion is coordinated by five carboxyl oxygens, two water molecules, and one cyano nitrogen, resulting in a eight-coordinate structure. The metalloligand $\left[\operatorname{Pt}(\mathrm{CN})_{2}\left(4,4^{\prime}-\mathrm{dcbpy}\right)\right]^{2-}$ is bound to five $\mathrm{Sr}(\mathrm{II})$ ions.

${ }_{25}$ The oxygen atoms from one of the two carboxyl groups (O3 and $\mathrm{O} 4)$ are bound to the $\mathrm{Sr}$ ion in a simple bidentate fashion. Although the oxygen atoms of another carboxyl group (O1 and $\mathrm{O} 2)$ are also coordinated to the $\mathrm{Sr}$ ion in a bidentate mode, these oxygen atoms also bridge to the adjacent $\mathrm{Sr}$ ions (Figure 3(b)),

30 resulting in the formation of a 1-D coordination chain along the $a$ axis. In contrast to MgPt-4.9 $\mathrm{H}_{2} \mathrm{O}$ and $\mathrm{CaPt}-4 \cdot 6 \mathrm{H}_{2} \mathrm{O}$, one of the two cyano ligands is bonded to the $\mathrm{Sr}$ ion. However, similar to CaPt-4. $6 \mathbf{H}_{2} \mathbf{O}$, the $\left[\mathrm{Pt}(\mathrm{CN})_{2}\left(4,4^{\prime} \text {-dcbpy }\right)\right]^{2-}$ units stack to form zigzag-type 1-D columns along the $a$ axis, as shown in Figure 35 3(b). In this column, the shortest distance between $\mathrm{Pt}(\mathrm{II})$ ions is 3.374(1) $\AA$, which is slightly longer than that in CaPt-4.6 $\mathbf{H}_{2} \mathbf{O}$ (3.3655(2) $\AA$ ), suggesting that the metallophilic interaction is slightly weaker in SrPt-4.3 $\mathbf{H}_{2} \mathbf{O}$. There are no effective $\pi-\pi$ interactions between adjacent dcbpy ligands in $\mathbf{S r P t}-\mathbf{4} \cdot \mathbf{3} \mathbf{H}_{2} \mathbf{O}$ in

40 this column. Owing to both the larger coordination and lower hydration numbers of the $\mathrm{Sr}$ (II) ion, this complex has the threedimensional coordination-bonded rigid structure shown in Figures 3(c) and (d). One of the three water molecules are not directly coordinated to any $\operatorname{Sr}($ II) ions, but are instead hydrogen45 bonded to the carboxyl oxygen or cyano nitrogen atoms. In this complex, 1-D water channels are also formed along the $a$ axis.

Figure 4(a) shows the structure of $\mathbf{B a P t}-\mathbf{4} \cdot \mathbf{5} \mathrm{H}_{2} \mathrm{O}$ in one asymmetric unit. The complex BaPt-4.5 $\mathbf{H}_{\mathbf{2}} \mathrm{O}$ crystallized in the monoclinic $P 2_{1} / n$ space group, and the crystal structure is very 50 similar to that of SrPt-4.3. $\mathrm{H}_{2} \mathrm{O}$. Similar to $\mathrm{CaPt}-\mathbf{4} \cdot \mathbf{6} \mathrm{H}_{2} \mathrm{O}$ and SrPt-4.3 $\mathrm{H}_{2} \mathrm{O}$, only one crystallographically independent $\mathrm{Ba}(\mathrm{II})$ ion and $\left[\operatorname{Pt}(\mathrm{CN})_{2}\left(4,4^{\prime}-\mathrm{dcbpy}\right)\right]^{2-}$ were found in the unit cell. The $\mathrm{Ba}$ (II) ion is surrounded by six carboxyl oxygens, two water molecules, and one cyano nitrogen, resulting in a nine-coordinate 55 structure. The metalloligand $\left[\operatorname{Pt}(\mathrm{CN})_{2}\left(4,4^{\prime}-\mathrm{dcbpy}\right)\right]^{2-}$ is bound to five $\mathrm{Ba}(\mathrm{II})$ ions, as shown in Figure 4(a). The oxygen atoms from one of the two carboxyl groups $(\mathrm{O} 3$ and $\mathrm{O} 4)$ are bound to the $\mathrm{Ba}$ ion in a bidentate fashion. Although the oxygen atoms of another
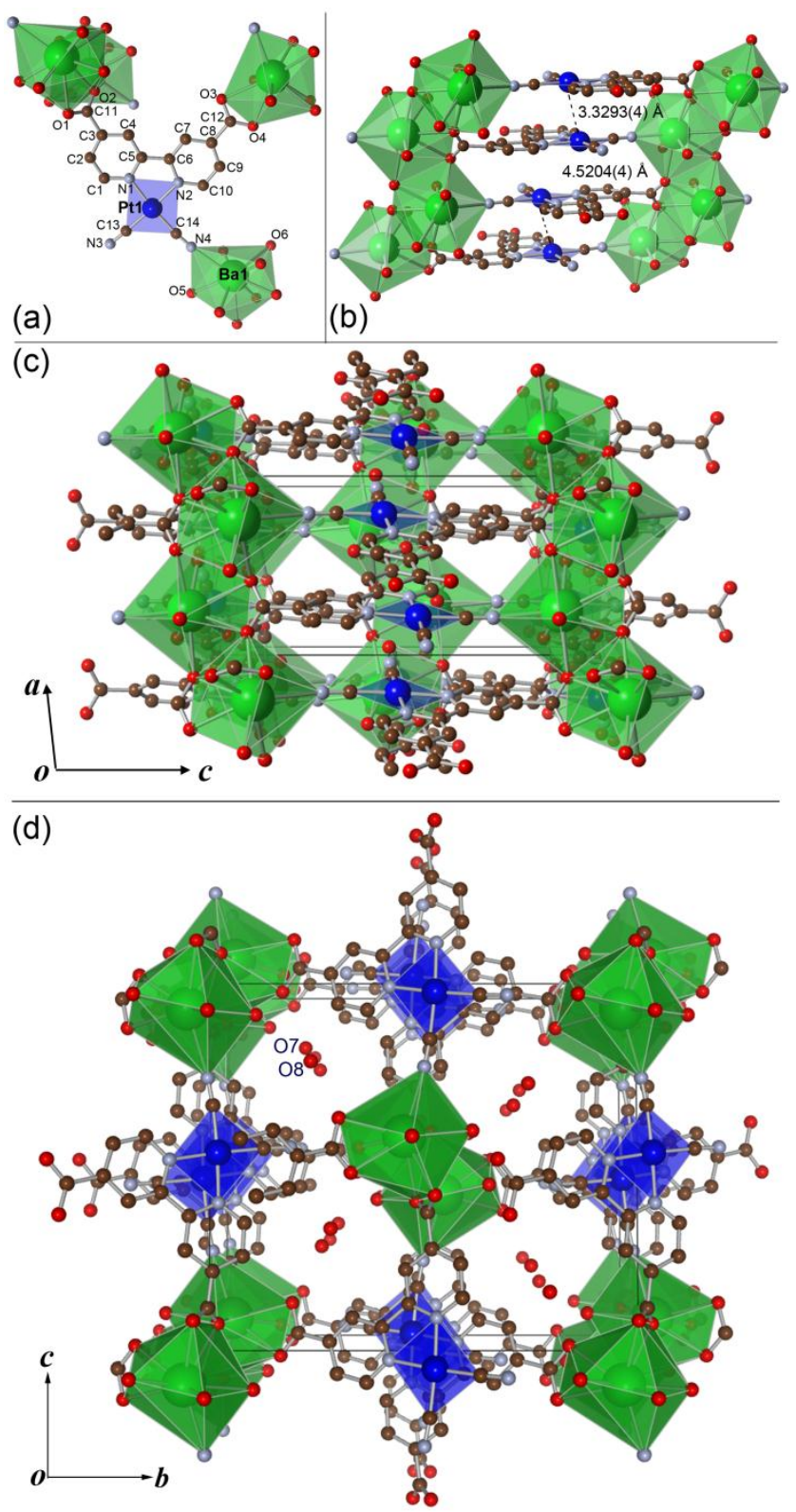

$60 \quad$ Fig. 4 (a) Asymmetric unit, (b) 1-D stacked structure, and (c) packing diagrams viewed down along the $b$ and (d) $a$ axes of BaPt-4 $\cdot 5 \mathbf{H}_{2} \mathrm{O}$. The coordination spheres of the $\mathrm{Pt}(\mathrm{II})$ and $\mathrm{Ba}(\mathrm{II})$ ions are shown as blue planes and green polyhedrons, respectively. The dotted lines represent the effective metallophilic interaction between $\mathrm{Pt}(\mathrm{II})$ ions. $\mathrm{H}$ atoms are

65 omitted for clarity. Solvated water molecules are omitted in (a), (b), and (c) for clarity. Brown, light-blue, and red spheres represent $\mathrm{C}, \mathrm{N}$, and $\mathrm{O}$ atoms, respectively. ${ }^{18}$

carboxyl group (O1 and $\mathrm{O} 2)$ are also coordinated to the $\mathrm{Ba}$ ion in a bidentate mode, these oxygen atoms also bridge to the adjacent ${ }_{70} \mathrm{Ba}$ ions (Figure 4(a)), resulting in the formation of a 1-D coordination chain along the $a$ axis. Similar to $\mathbf{S r P t}-4 \cdot 3 \mathrm{H}_{2} \mathrm{O}$, one of the two cyano ligands is bonded to the $\mathrm{Ba}$ (II) ion. The $\left[\operatorname{Pt}(\mathrm{CN})_{2}\left(4,4^{\prime}-\mathrm{dcbpy}\right)\right]^{2-}$ units stack to form zigzag-type 1-D columns along the $a$ axis, as shown in Figure 4(b). In this column, 75 the shortest distance between Pt(II) ions is 3.3293(4) $\AA$, which is

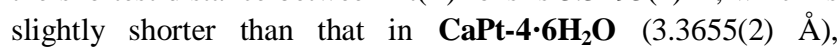
suggesting that the metallophilic interaction is more pronounced in BaPt-4.5 $\mathbf{H}_{2} \mathbf{O}$. There are no effective $\pi-\pi$ interactions between 
adjacent dcbpy ligands in BaPt-4.5 $\mathbf{H}_{2} \mathbf{O}$ in this column. Owing to both the larger coordination and lower hydration numbers of the $\mathrm{Ba}(\mathrm{II})$ ion, this complex has the three-dimensional coordinationbonded rigid structure shown in Figures 4(c) and (d). Three of the 5 five water molecules are not directly coordinated to any $\mathrm{Ba}$ (II) ions, but are instead hydrogen-bonded to the carboxyl oxygen or cyano nitrogen atoms. In this complex, 1-D water channels are also formed along the $a$ axis.

As discussed above, the heavier and larger alkaline-earth metal 10 ions tend to form higher-dimensional coordination-network structures. This trend is probably due to the larger ionic radius of the metal ions and the smaller hydration enthalpy. As the ionic radius of an ion grows larger, the ion adopts a larger coordination number. In addition, an ion with a smaller absolute value of 15 hydration enthalpy would tend to form an ionic bond with the anionic ligand-like carboxylate rather than a neutral water molecule. Consequently, the variation of the alkaline-earth metal ion in this MPt-4 $\boldsymbol{n} \mathbf{H}_{2} \mathbf{O}$ series enables us to modify not only the hydration number but also the rigidity and dimensionality of the 20 coordination-network structure.

\section{Thermochromic luminescence.}

Figure 5 shows the temperature dependence of the luminescence

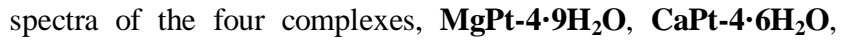

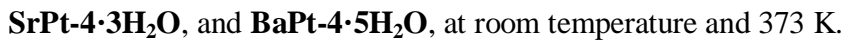
25 The photophysical properties of these complexes are summarized in Table 2. The synthesized pale-yellow crystals of MgPt4.9 $\mathrm{H}_{2} \mathrm{O}$ and CaPt-4.6 $\mathrm{H}_{2} \mathrm{O}$ showed greenish yellow luminescence. The spectrum with vibronic structures with a

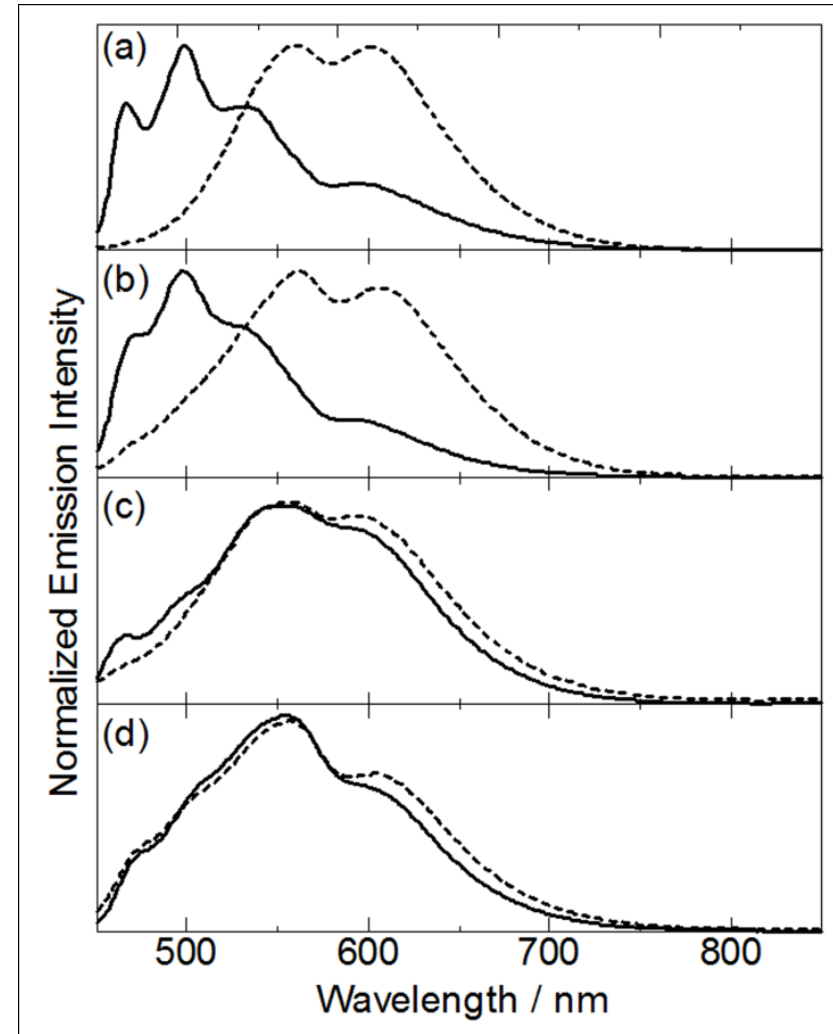

30 Fig. 5 Temperature dependences of luminescence spectra of (a) MgPt-

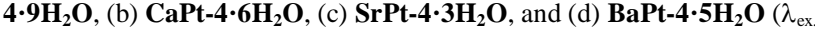
$=400 \mathrm{~nm}$ ). The solid and broken lines represent the spectra at room temperature and $373 \mathrm{~K}$, respectively.
Table 2 Photophysical properties of MPt-4 $\cdot n \mathbf{H}_{2} \mathrm{O}$ complexes.

\begin{tabular}{|c|c|c|c|c|}
\hline Complex & $\lambda_{\mathrm{em} .} \underset{a}{(\mathrm{RT})}$ & $\begin{array}{l}\left(100{ }^{\circ} \mathrm{C}\right) / \\
\mathrm{nm}^{a}\end{array}$ & $\tau_{\mathrm{em} .}(\mathrm{RT}) / \mu \mathrm{s}^{b}$ & $\Phi_{\mathrm{em} .}(\mathrm{RT})^{a}$ \\
\hline MgPt-4.9 $\mathrm{H}_{2} \mathrm{O}$ & 498 & 560 & 3.25 & 0.21 \\
\hline CaPt-4. $6 \mathrm{H}_{2} \mathrm{O}$ & 498 & 562 & 1.47 & 0.27 \\
\hline SrPt-4. $3 \mathrm{H}_{2} \mathrm{O}$ & 557 & 555 & 0.27 & 0.09 \\
\hline BaPt-4 $5 \mathrm{H}_{2} \mathrm{O}$ & 555 & 557 & 0.48 & 0.11 \\
\hline
\end{tabular}

maximum at $498 \mathrm{~nm}$ is assignable to the emission from the ${ }^{3} \pi-\pi^{*}$ state, which is mainly localized on the dcbpy ligand. Although the emission maxima of the other two complexes were observed at $556 \mathrm{~nm}$, the vibronic structures are almost the same as those of ${ }_{40} \mathbf{M g P t}-\mathbf{4} \cdot \mathbf{6} \mathrm{H}_{2} \mathrm{O}$ and $\mathbf{C a P t}-\mathbf{4} \cdot \mathbf{6} \mathbf{H}_{\mathbf{2}} \mathbf{O}$, implying that they originate from the same ${ }^{3} \pi-\pi^{*}$ emission. The observed relatively long emission lifetimes, which ranged from 0.27 to $3.25 \mu \mathrm{s}$ for the MPt-4 complexes, are also consistent with this assignment. As discussed earlier, the shortest intermolecular distances between ${ }_{45} \mathrm{Pt}$ (II) ions in these complexes suggest that metallophilic interactions are not present in $\mathbf{M g P t}-\mathbf{4} \cdot \mathbf{9} \mathrm{H}_{2} \mathrm{O}$, but are effective in CaPt-4. $6 \mathrm{H}_{2} \mathrm{O}$ and BaPt-4.5 $\mathbf{H}_{2} \mathrm{O}$, which feature shortest intermolecular Pt...Pt distances of 3.3655(2) and 3.3293(4) $\AA$, respectively. It is well known that one-dimensionally stacked ${ }_{50} \mathrm{Pt}$ (II) complexes with effective metallophilic interactions usually exhibit strong phosphorescence from the triplet metal-metal-toligand charge-transfer $\left({ }^{3} \mathrm{MMLCT}\right)$ state. ${ }^{3-4}$ Nevertheless, the origin of the emission for each MPt-4 is the ${ }^{3} \pi-\pi^{*}$ state, implying that the metallophilic interactions in CaPt-4.6 $\mathrm{H}_{2} \mathrm{O}$ and

${ }_{55} \mathrm{BaPt}-4 \cdot \mathbf{H}_{2} \mathrm{O}$ are not strong enough to change the emission origin from the ${ }^{3} \pi-\pi^{*}$ to the ${ }^{3}$ MMLCT state. In fact, the relatively long emission lifetimes of about $1 \mu \mathrm{s}$ and their characteristic vibronic structures in the emission spectra are quite comparable to the emission from the ${ }^{3} \pi-\pi *($ bpy $)$ state observed ${ }_{60}$ for $\left[\mathrm{Pt}(\mathrm{CN})_{2}\left(\mathrm{dC}_{9} \mathrm{bpy}\right)\right]\left(\mathrm{dC}_{9}\right.$ bpy $=4,4^{\prime}$-dinonyl-2,2'-bipyridine $)$ in a $\mathrm{CHCl}_{3}$ solution. ${ }^{2 \mathrm{i}}$ It is noteworthy that after heating to $373 \mathrm{~K}$, the

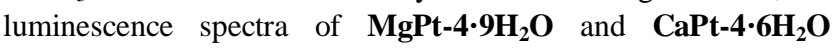
changed to spectra similar to those of the other two MPt-4 (M = $\mathrm{Sr}^{2+}$ and $\mathrm{Ba}^{2+}$ ) featuring two main emission bands at 560 and 602 $65 \mathrm{~nm}$. The emission lifetime of $\mathbf{M g P t}-\mathbf{4} \cdot \mathbf{9 H}_{2} \mathrm{O}$ after heating at 373 $\mathrm{K}$ was about $0.3 \mu \mathrm{s}$, which is about one-tenth of the lifetime of the room-temperature MgPt-4.9H $\mathbf{~} \mathrm{O}$ and comparable to that of

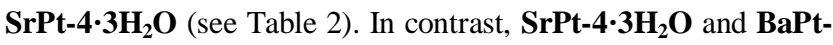
$\mathbf{4} \cdot \mathbf{5} \mathrm{H}_{2} \mathrm{O}$ showed almost temperature-independent luminescence. ${ }_{70}$ In both cases, the similar vibronic structures observed in the spectra suggest that the emission origin, i.e., the ${ }^{3} \pi-\pi^{*}$ state, remains unchanged.

In order to account for the mechanisms of the thermochromic luminescence, thermogravimetric (TG) analysis and powder X75 ray diffraction (PXRD) measurement were performed. TG analyses of the four MPt-4 $\boldsymbol{n} \mathbf{H}_{2} \mathrm{O}$ complexes revealed that heating at $373 \mathrm{~K}$ removed almost all of the water molecules to form anhydrous MPt-4 (see Figure S1). Figure 6 shows the changes in the PXRD patterns of MgPt-4.9H $\mathbf{H}_{2} \mathrm{O}$ and CaPt${ }_{80} \mathbf{4} \cdot \mathbf{6 H}_{2} \mathrm{O}$. The PXRD patterns observed for anhydrous MgPt-4 and CaPt-4 after drying $\mathbf{M g P t}-\mathbf{4} \cdot \mathbf{9 H _ { 2 }} \mathrm{O}$ and $\mathbf{C a P t}-\mathbf{4} \cdot \mathbf{6} \mathrm{H}_{2} \mathrm{O}$ at 373 $\mathrm{K}$ for 1 day were completely different to those of the original hydrates. In contrast, the PXRD pattern of BaPt-4.5 $\mathbf{H}_{2} \mathrm{O}$ was not changed after increasing the temperature (see Figure S2). Thus, 85 the thermochromic luminescences of both complexes are 


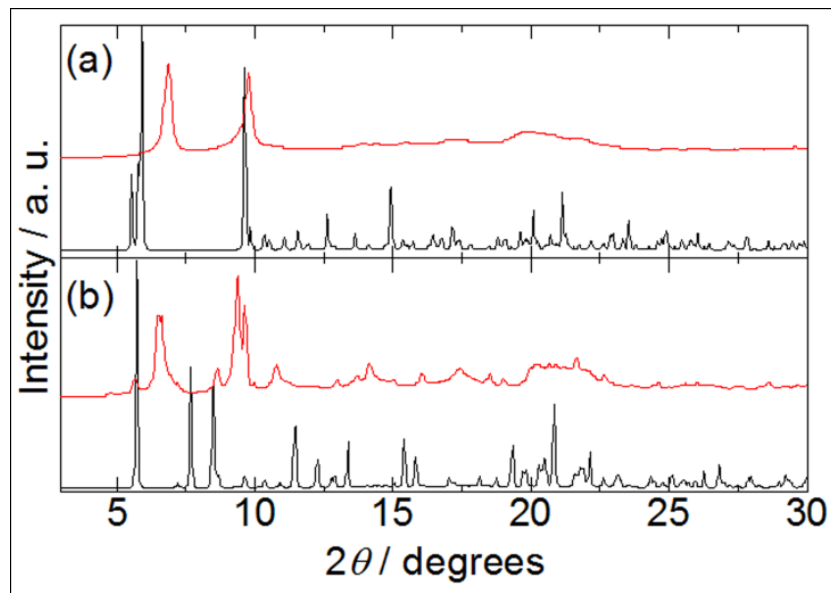

Fig. 6 Temperature dependence of PXRD patterns of (a) $\mathbf{M g P t}-\mathbf{4} \cdot \mathbf{9} \mathrm{H}_{2} \mathrm{O}$ and (b) $\mathbf{C a P t}-\mathbf{4} \cdot 6 \mathrm{H}_{2} \mathrm{O}$. The black and red lines represent the diffraction patterns at room temperature and $373 \mathrm{~K}$, respectively.

5 considered to be driven by a structural transformation caused by the release of the water molecules. The emission maxima and vibronic structures of MgPt-4 and CaPt-4 are comparable and similar to those of BaPt-4.5 $\mathbf{H}_{2} \mathrm{O}$ and $\mathbf{S r P t}-\mathbf{4} \cdot \mathbf{3} \mathrm{H}_{2} \mathrm{O}$, implying that the structures of anhydrous MgPt-4 and CaPt-4 may be 10 similar to that of $\mathbf{B a P t}-\mathbf{4} \cdot \mathbf{5} \mathbf{H}_{\mathbf{2}} \mathbf{O}$, which has a 3-D coordinationbonded network structure. This structural transformation would affect the rigidity of the crystal lattice, leading to a change in the vibronic structures of their luminescence spectra.

Vapochromic and mechanochromic luminescence of $15 \mathrm{MgPt} \cdot 9 \mathrm{H}_{2} \mathrm{O}$.

In this section, we discuss the multichromic luminescence of MgPt-4.9H $\mathrm{H}_{2} \mathrm{O}$ in detail because it is the only complex that exhibits vapochromic and mechanochromic behaviours. Figure 7

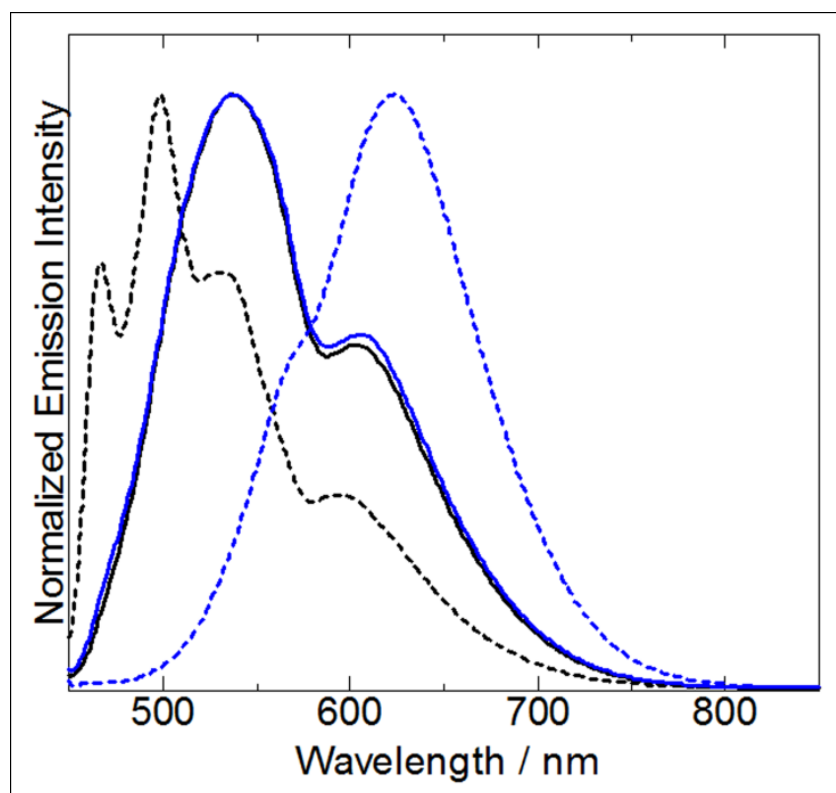

20 Fig. 7 Luminescence spectral changes in $\mathbf{M g P t}-\mathbf{4} \cdot \mathbf{9 H}_{2} \mathrm{O}$ by mechanical grinding and exposure to $\mathrm{MeOH}$ vapour $\left(\lambda_{\text {ex. }}=400 \mathrm{~nm}\right)$. The black and blue lines represent the spectra of as-synthesized and crushed crystals, respectively, whereas the dotted and solid lines represent the spectra before and after exposure to $\mathrm{MeOH}$ vapour for 1 day at room temperature, 25 respectively. shows the luminescence spectral changes in MgPt-4.9H $\mathbf{H}_{2} \mathrm{O}$ after grinding for $10 \mathrm{~min}$ and after exposing the samples to $\mathrm{MeOH}$ vapour for 1 day. The luminescence spectrum of the assynthesized crystals changed from a greenish yellow ${ }^{3} \pi-\pi^{*}$ 30 emission to a yellow emission centered at $537 \mathrm{~nm}$ with a shoulder at $607 \mathrm{~nm}$ after exposure to the $\mathrm{MeOH}$ vapour. The colour and emission were also changed to a reddish orange emission centered at $624 \mathrm{~nm}$ after mechanical grinding of the crystals, as shown in Figures 7 and 8. Interestingly, after exposing the 35 crushed sample to $\mathrm{MeOH}$ vapour, it had almost the same yellow emission, with a maximum at $537 \mathrm{~nm}$, as the as-synthesized crystals that had been exposed to $\mathrm{MeOH}$ vapour. The original emission of MgPt-4.9H $\mathbf{H}_{2} \mathrm{O}$ was gradually recovered by immersing these samples in water, even though $\mathbf{M g P t}-\mathbf{4} \cdot \mathbf{9 H _ { 2 }} \mathrm{O}$ is 40 nearly insoluble in water. As summarized in Scheme 1, these

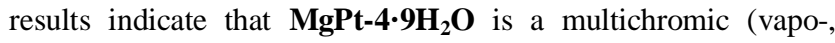
mechano-, and thermochromic) luminescent complex.

To investigate the mechanism of the vapochromic and mechanochromic behaviours, we measured PXRD patterns under 45 various conditions. Figure 9 shows the changes in the PXRD pattern of MgPt-4.9H2 $\mathrm{O}$ upon mechanical grinding and exposure to $\mathrm{MeOH}$ vapour. Both the as-synthesized and crushed crystals showed almost the same diffraction patterns, suggesting that the
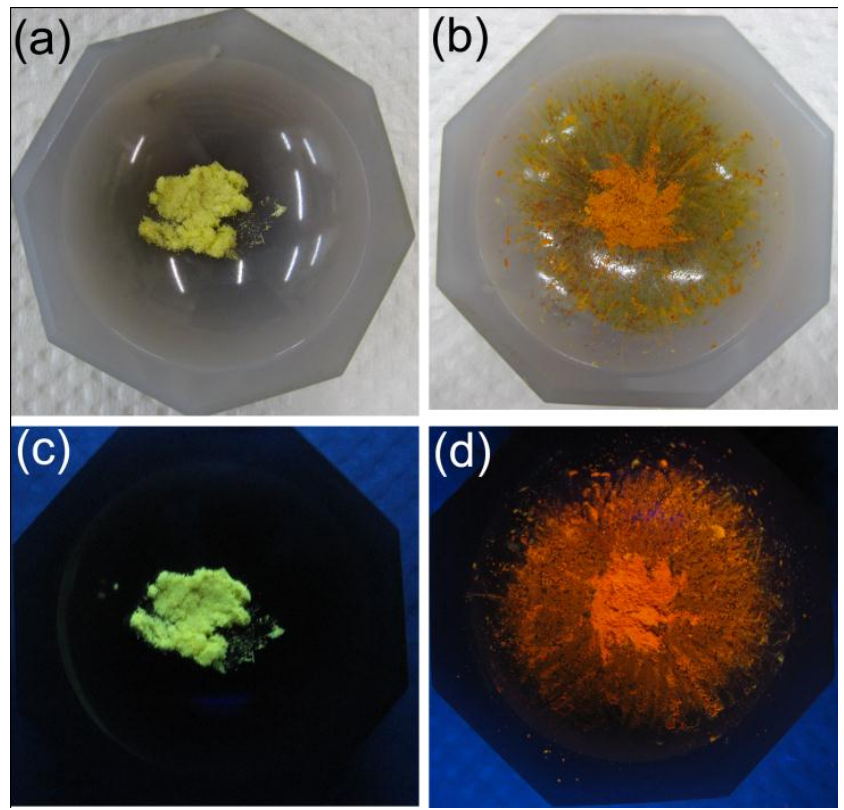

$50 \quad$ Fig. 8 Mechanochromic behaviour of $\mathbf{M g P t}-4 \cdot 9 \mathbf{H}_{2} \mathbf{O}$. The upper and lower images are bright-field and luminescence images of (a, c) assynthesized and (b, d) crushed crystals of MgPt-4.9. $\mathbf{H}_{2} \mathrm{O}$, respectively.



Scheme 1 Schematic diagram summarizing the multichromic behaviour 55 of MgPt-4.9H $\mathrm{H}_{2} \mathrm{O}$. 


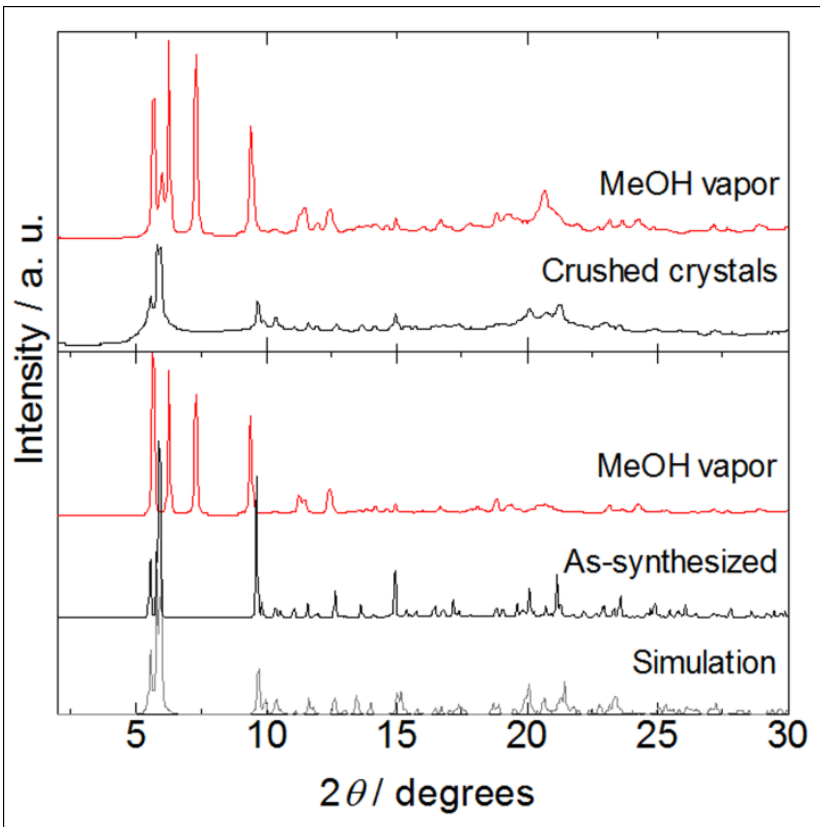

Fig. 9 Changes in the PXRD patterns of as-synthesized and crushed crystals of MgPt-4.9H $\mathrm{H}_{2} \mathrm{O}$ upon exposure to $\mathrm{MeOH}$ vapour for 2 days at room temperature $(\lambda=1.200(1) \AA)$. The bottom gray pattern shows the simulation calculated from the crystal structure of $\mathbf{M g P t}-\mathbf{4} \cdot \mathbf{9} \mathrm{H}_{2} \mathrm{O}$

long-range structure of $\mathbf{M g P t}-\mathbf{4} \cdot \mathbf{9 H}_{2} \mathrm{O}$ was retained after mechanical grinding. It may be noted that the peak intensities and widths in the crushed sample were weaker and broader than those of the as-synthesized crystals in spite of the fact that both 10 originated from the same amount of sample, which implies that the crystalline MgPt-4.9H $\mathbf{H}_{2} \mathrm{O}$ was partly transformed to an amorphous solid by mechanical grinding. A remarkable change was observed in the IR spectrum of the crushed $\mathrm{MgPt}-4 \cdot 9 \mathrm{H}_{2} \mathrm{O}$. As shown in Figure 10(a), the overall spectral features of the as15 synthesized and crushed crystals were quite similar. However, the $v(\mathrm{C} \equiv \mathrm{N})$ mode of the cyano ligand was observed as two bands in the as-synthesized crystals, whereas it was observed as two bands with a shoulder at $2138 \mathrm{~cm}^{-1}$ in the crushed sample, which was not observed for any of the other crushed MPt-4 $\boldsymbol{n} \boldsymbol{n} \mathbf{H}_{\mathbf{2}} \mathbf{O}$ crystals 20 (see Figure S3). In addition, the elemental analysis of the crushed sample revealed that its chemical composition is the same as that of the as-synthesized MgPt-4.9H $\mathbf{~} \mathrm{O}$ (see supporting information). Thus, these results suggest that the observed mechanochromic behaviour of MgPt-4.9H $\mathbf{H}_{2} \mathrm{O}$ originates from the local structural 25 change around the cyano ligand which might enhance the intermolecular metallophilic and/or $\pi-\pi$ stacking interactions between the adjacent Pt(II) metalloligands. The PXRD pattern of as-synthesized $\mathbf{M g P t}-\mathbf{4} \cdot \mathbf{9 H}_{2} \mathrm{O}$ also significantly changed upon its exposure to $\mathrm{MeOH}$ vapour. As shown in Figure 9, new intense 30 diffraction peaks appeared at $6.2^{\circ}, 7.3^{\circ}$, and $9.4^{\circ}$. A similar diffraction pattern was observed for the sample obtained from the

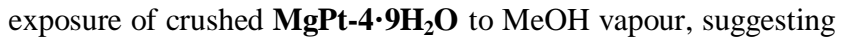
that the structures of as-synthesized and crushed $\mathrm{MgPt}-4 \cdot 9 \mathrm{H}_{2} \mathrm{O}$ were the same after exposure to $\mathrm{MeOH}$ vapour. In the IR 35 spectrum of $\mathbf{M g P t}-\mathbf{4} \cdot \mathbf{9 H}_{\mathbf{2}} \mathrm{O}$ that was exposed to $\mathrm{MeOH}$ vapour, the broad band assigned to the $v(\mathrm{O}-\mathrm{H})$ mode of water molecules, appearing at $3400 \mathrm{~cm}^{-1}$, seems to shift to a lower wavenumber as shown in Figure 10(b). New bands, assignable to the C-H, and C-

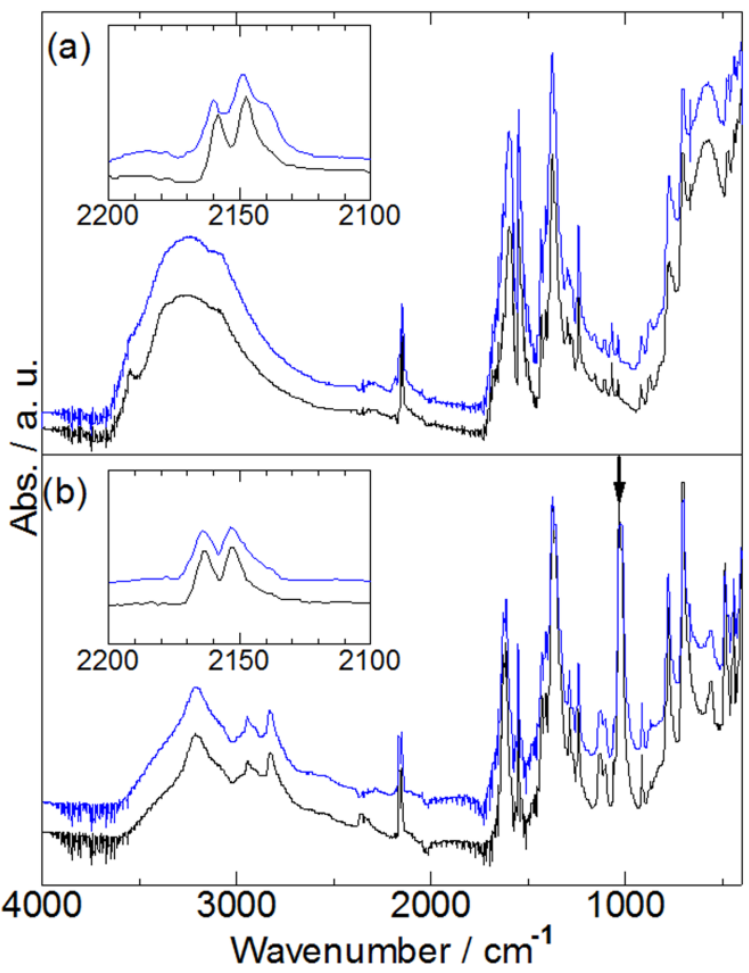

$40 \quad$ Fig. 10 IR spectra of as-synthesized (black) and crushed powder (blue) MgPt-4.9H $\mathrm{H}_{2} \mathrm{O}$ after exposure to (a) air and (b) $\mathrm{MeOH}$ vapour for 1 day. Insets show the expansion of the $v(\mathrm{C} \equiv \mathrm{N})$ vibration band region around $2150 \mathrm{~cm}^{-1}$. The black arrow shown in (b) indicates the $v(\mathrm{C}-\mathrm{O})$ band of the adsorbed $\mathrm{MeOH}$.

${ }_{45} \mathrm{O}$ stretching mode of the adsorbed $\mathrm{MeOH}$ molecule, were observed at 2944, 2829 and $1033 \mathrm{~cm}^{-1}$, respectively, which are comparable to that of normal liquid $\mathrm{MeOH}$. Similarly, under exposure the as-synthesized $\mathbf{M g P t}-\mathbf{4} \cdot \mathbf{9 H}_{2} \mathrm{O}$ to methanol- $\mathrm{d}_{4}$ vapour at room temperature, the bands assigned to $v(\mathrm{O}-\mathrm{D}), \mathrm{v}(\mathrm{C}$ $\left.{ }_{50} \mathrm{D}\right)$ and $v(\mathrm{C}-\mathrm{O})$ bands of methanol- $\mathrm{d}_{4}$ were appeared at around 2493, 2074 and $985 \mathrm{~cm}^{-1}$ and gradually increased, those energies are quite comparable to the normal liquid of methanol- $\mathrm{d}_{4}$ (see Figure S4). These results suggest that the adsorbed $\mathrm{MeOH}$ molecule was not directly bonded to the $\mathrm{Mg}$ (II) ion. In the case of 55 the crushed sample, the characteristic $v(\mathrm{C} \equiv \mathrm{N})$ band at $2138 \mathrm{~cm}^{-1}$ disappeared after exposure to $\mathrm{MeOH}$ vapour. In addition, elemental analysis of the sample obtained after the exposure of MgPt-4.9H $\mathrm{H}_{2} \mathrm{O}$ to $\mathrm{MeOH}$ vapour for 1 day also suggests that three of the nine water molecules were replaced by one $\mathrm{MeOH}$ ${ }_{60}$ molecule to form $\mathbf{M g P t}-\mathbf{4} \cdot \mathbf{6 H}_{\mathbf{2}} \mathbf{O} \cdot \mathbf{M e O H}$ (see supporting information). In the TG-DTA analysis of the sample exposed to $\mathrm{MeOH}$ vapour, the gradual weight loss about $20.0 \%$ (at $400 \mathrm{~K}$ ) was observed, which corresponds to the removal of all solvated water and methanol molecules in $\mathbf{M g P t}-4 \cdot 6 \mathrm{H}_{2} \mathrm{O} \cdot \mathbf{M e O H}$. In 65 addition, three endothermic peaks at 308,325 , and $335 \mathrm{~K}$ were observed for the methanol exposed sample, whereas the original MgPt-4.9H $\mathrm{H}_{2} \mathrm{O}$ showed only one endothermic peak at $321 \mathrm{~K}$ (see Figure S5). Thus, the vapochromic behaviour of $\mathbf{M g P t}-4 \cdot 9 \mathrm{H}_{2} \mathrm{O}$ is thought to originate from the exchange of water with $\mathrm{MeOH}$, 70 which induces a molecular rearrangement of the solid state. As mentioned above, four of the nine water molecules were not 
bonded to the $\mathrm{Mg}$ (II) ion and formed 1-D water channels along the $a$ axis, which may enable their easy exchange with $\mathrm{MeOH}$. Although we have not yet succeeded in the structural determination of $\mathbf{M g P t}-\mathbf{4} \cdot \mathbf{6} \mathrm{H}_{\mathbf{2}} \mathrm{O} \cdot \mathbf{M e O H}$, its emission energy and 5 spectral shape suggest that the molecular rearrangement induced by guest exchange may enhance the intermolecular metallophilic and/or $\pi-\pi$ stacking interaction, leading to a red shift of the emission band.

\section{Effect of the position of carboxyl group in the metalloligand.}

10 As mentioned in Introduction, we have previously reported the structures and chromic behaviours of the luminescent coordination polymers, MPt-5 $n \mathrm{H}_{2} \mathrm{O}$ built from divalent $\mathrm{M}^{2+}$ ions $\left(\mathrm{M}=\mathrm{Zn}^{2+}, \mathrm{Mg}^{2+}, \mathrm{Ca}^{2+}, \mathrm{Sr}^{2+}\right.$, and $\mathrm{Ba}^{2+}$ ) and the isomeric metalloligand $\left[\mathrm{Pt}(\mathrm{CN})_{2}\left(5,5^{\prime}-\mathrm{dcbpy}\right)\right]^{2-} .8$ In this section, we discuss 15 the effect of the position of carboxyl group on the metalloligand based on the comparison between MPt-5 and MPt-4 systems.

In the structures of MPt-5. $n \mathrm{H}_{2} \mathrm{O}$, one-dimensional coordination-bonded chain structure constructed by the alternate arrangement of $\mathrm{M}^{2+}$ ion and the metalloligand $\left[\mathrm{Pt}(\mathrm{CN})_{2}\left(5,5^{\prime}-\right.\right.$ 20 dcbpy) $]^{2-}$ are commonly formed and the metallophilic interaction between $\mathrm{Pt}(\mathrm{II})$ ions is effective in all MPt-5 $\cdot \mathrm{nH}_{2} \mathrm{O}$ complexes (scheme 2(a)). The bridging $\mathrm{M}^{2+}$ ions are bound by two carboxylate groups of the metalloligand at the axial position and several water molecules in the equatorial plane. The hydration 25 numbers $(n=4 \sim 5)$ of MPt-5 complexes are almost independent of the $\mathrm{M}^{2+}$ ion. By contrast, the crystal structures of MPt-4 complexes strongly depend on the $\mathrm{M}^{2+}$ ion (scheme 2(b)). Except

(a)

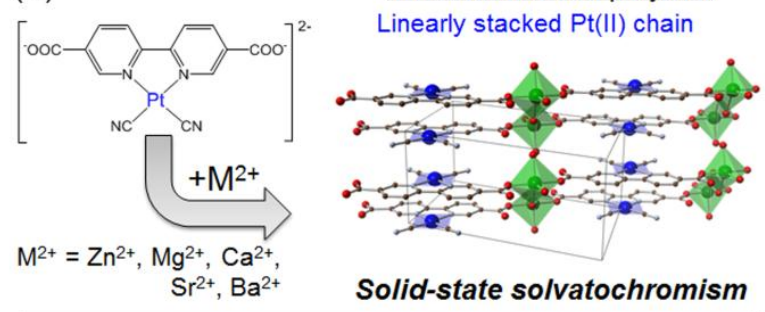

(b)

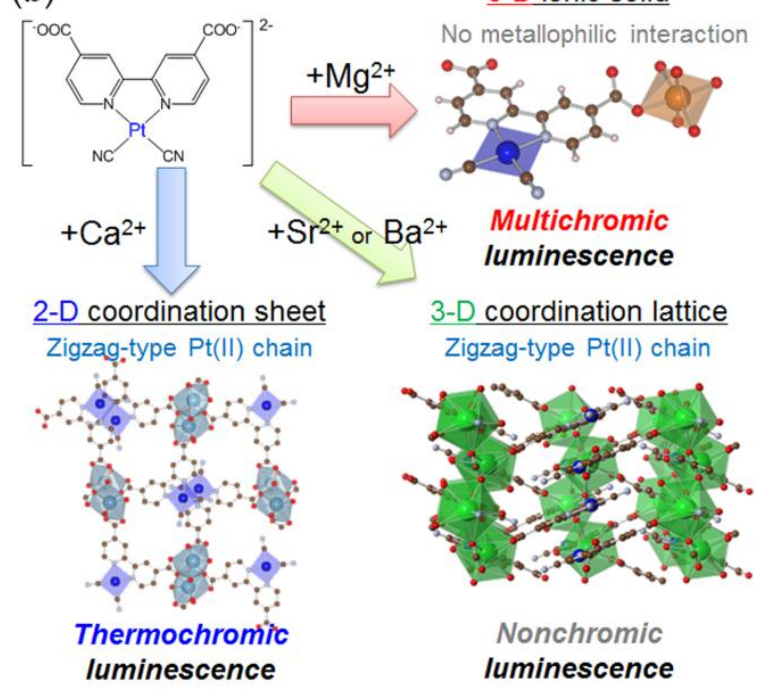

Scheme 2 Schematic diagram summarizing the differences of structures 30 and luminescence properties between (a) MPt-5 and (b) MPt-4 systems. for the MgPt-4.9 $\mathrm{H}_{2} \mathrm{O}$, the bridging $\mathrm{M}^{2+}$ ions are surrounded by two or three carboxylate groups of the metalloligand, and the hydration numbers of MPt-4 complexes strongly depend on the $\mathrm{M}^{2+}$ ion and are in the range from 3 to 9 . It should be emphasized 35 that the intermolecular metallophilic interaction in the MPt-5 system is thought to be effective in the uniformly stacked $\mathrm{Pt}(\mathrm{II})$ complex columns, whereas it is only effective in the dimerized structure in all the fully-hydrated MPt-4 $n \mathrm{H}_{2} \mathrm{O}$ complexes except for the MgPt-4.9 $\mathrm{H}_{2} \mathrm{O}$ in which there is no metallophilic 40 interaction. In addition, the sodium salt of the metalloligand, $\mathrm{Na}_{2}\left[\operatorname{Pt}(\mathrm{CN})_{2}\left(4,4^{\prime}-\mathrm{dcbpy}\right)\right] \cdot 5 \mathrm{H}_{2} \mathrm{O}$ has also no metallophilic interaction. ${ }^{6 p}$ Consequently, emission properties of MPt-5 and MPt-4 systems are quite different to each other, i.e., the MPt-5 complexes exhibit the red emission derived from the ${ }^{3}$ MMLCT 45 state with relatively short emission lifetime $\left(\tau_{\mathrm{em} .}=25-69 \mathrm{~ns}\right)$ with small quantum yields $\left(\Phi_{\mathrm{em}}=0.05-0.12\right)$, whereas the MPt4 complexes shows the green to yellow emission originating from the ${ }^{3} \pi-\pi *$ excited state with long emission lifetime $\left(\tau_{\mathrm{em} .}=0.27\right.$ $3.27 \mu \mathrm{s})$ and large quantum yields $\left(\Phi_{\mathrm{em}}=0.09-0.27\right)$. In addition, 50 the MPt-5 complexes commonly exhibit interesting solid-state solvatochromic behaviour driven by the adsorption/desorption of the hydration water molecules, whereas the chromic behaviours of MPt-4 complexes strongly depend on the $\mathrm{M}^{2+}$ ion as discussed above. These differences clearly indicate that the position of the 55 carboxyl group attached on the bipyridine ligand plays an important role on these MPt systems. Considering the fact that the acid-dissociation constants of 4,4'- $\mathrm{H}_{2} \mathrm{dcbpy}$ and 5,5'- $\mathrm{H}_{2} \mathrm{dcbpy}$ are very close to each other, ${ }^{17}$ the positional difference of the coordination-bonding site gives considerable effects on the ${ }_{60}$ coordination-network structures including the intermolecular metallophilic interaction. In addition, more negative reduction potential of the 4,4'-dcbpy ligand than that of 5,5'-dcbpy ${ }^{17}$ may affect the emission properties of these $\mathrm{Pt}(\mathrm{II})$-diimine-based complex salts.

\section{${ }_{65}$ Conclusion}

We synthesized four new Pt(II)-diimine-based complex salts with alkaline-earth metal ions, namely, $\left\{\left[\mathrm{Mg}\left(\mathrm{H}_{2} \mathrm{O}\right)_{5}\right]\left[\mathrm{Pt}(\mathrm{CN})_{2}(4,4\right.\right.$ ' dcbpy) $\left.] \cdot 4 \mathrm{H}_{2} \mathrm{O}\right\} \quad\left(\mathbf{M g P t}-4 \cdot 9 \mathrm{H}_{2} \mathrm{O}\right), \quad\left\{\left[\mathrm{Ca}\left(\mathrm{H}_{2} \mathrm{O}\right)_{3}\right]\left[\mathrm{Pt}(\mathrm{CN})_{2}\left(4,4^{\prime}-\right.\right.\right.$ dcbpy) $\left.] \cdot 3 \mathrm{H}_{2} \mathrm{O}\right\} \quad\left(\mathbf{C a P t}-\mathbf{4} \cdot \mathbf{6} \mathbf{H}_{2} \mathrm{O}\right), \quad\left\{\left[\mathrm{Sr}\left(\mathrm{H}_{2} \mathrm{O}\right)_{2}\right]\left[\mathrm{Pt}(\mathrm{CN})_{2}\left(4,4^{\prime}-\right.\right.\right.$ $\left.70 \mathrm{dcbpy})] \cdot \mathrm{H}_{2} \mathrm{O}\right\} \quad\left(\mathbf{S r P t}-\mathbf{4} \cdot \mathbf{3} \mathrm{H}_{2} \mathrm{O}\right)$, and $\left\{\left[\mathrm{Ba}\left(\mathrm{H}_{2} \mathrm{O}\right)_{2}\right]\left[\mathrm{Pt}(\mathrm{CN})_{2}\left(4,4{ }^{\prime}-\right.\right.\right.$ dcbpy) $\left.] \cdot 3 \mathrm{H}_{2} \mathrm{O}\right\} \quad\left(\mathbf{B a P t}-\mathbf{4} \cdot \mathbf{5} \mathbf{H}_{2} \mathrm{O}\right)$. Single-crystal X-ray structural determination revealed that there were water channels in their crystals and that the metallophilic interaction between $\mathrm{Pt}(\mathrm{II})$ ions was negligibly weak in MgPt-4.9. $\mathbf{H}_{2} \mathrm{O}$ and moderate in the other 75 three MPt-4 $\cdot \mathbf{n H}_{\mathbf{2}} \mathbf{O}$, which formed dimerized structures. There was no coordination network in the MgPt-4.9H $\mathbf{H}_{2} \mathrm{O}$, but two- and three-dimensional rigid coordination networks were formed in CaPt-4. $6 \mathrm{H}_{2} \mathrm{O}$ and the other two complexes, respectively. These structures are quite different to the Pt(II)-diimine-based MPt-5 80 system with the isomeric metalloligand, $\left[\mathrm{Pt}(\mathrm{CN})_{2}\left(5,5^{\prime}-\mathrm{dcbpy}\right)\right]^{2-}$. All of the complexes exhibited ${ }^{3} \pi-\pi^{*}$ emission with similar vibronic structures. MgPt-4.9. $\mathbf{H}_{2} \mathrm{O}$ was found to be triplechromic (thermo-, mechano-, and vapochromic) luminescent

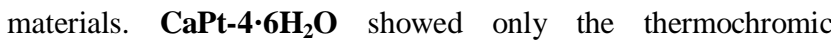
85 luminescence and the other two complexes that featured heavier alkaline-earth metal ions did not exhibit any chromic behaviour. The thermochromic luminescence of the former two complexes is 
mainly derived from the adsorption/desorption of water. The large amount of water molecules included in $\mathbf{M g P t}-\mathbf{4} \cdot \mathbf{9 H}_{2} \mathrm{O}$ may enable it to respond to guest exchange and mechanical grinding, leading to the interesting multichromic luminescence. Further 5 study on the fine tuning of the structural flexibility to control the multichromic behaviour is now in progress.

\section{Acknowledgements}

We thank Prof. S. Noro (Hokkaido Univ.) for his kind experimental support and helpful discussion. This work is 10 supported by a Grant-in-Aid for Scientific Research (B)(23350025), Photochromism (No.471), Coordination Programming (No. 2107), Young Scientists (B) (19750050), and the Global COE Program (Project No. B01: Catalysis as the Basis for Innovation in Materials Science) from MEXT, Japan.

\section{${ }_{15}$ Notes and references}

${ }^{a}$ Division of Chemistry, Faculty of Science, Hokkaido University, North10 West-8, Kita-ku, Sapporo 060-0810, Japan. Fax: 81-11-706-3447; Tel:81-11-706-3817; E-mail: akoba@sci.hokudai.ac.jp (A.K.), mkato@sci.hokudai.ac.jp (M. K.)

$20 \dagger$ Electronic Supplementary Information (ESI) available: X-ray crystallographic files in CIF format (CCDC reference numbers 829255, 829256, 848114 and 829257); TG curves of the MPt-4 $\boldsymbol{n} \mathbf{H}_{\mathbf{2}} \mathbf{O}$ series; PXRD patterns of BaPt-4.5 $\mathbf{H}_{2} \mathbf{O}$ at 298 and $373 \mathrm{~K}$; IR spectra of assynthesized and crushed crystals of CaPt-4.6 $\mathrm{H}_{2} \mathrm{O}$; IR spectral change of 25 as-synthesized MgPt-4.9. $\mathbf{H}_{2} \mathrm{O}$ under exposure to methanol- $\mathrm{d}_{4}$ vapour; TGDTA curves of MgPt-4.9. $\mathrm{H}_{2} \mathrm{O}$ and $\mathrm{MgPt}-4 \cdot 6 \mathrm{H}_{2} \mathrm{O} \cdot \mathbf{M e O H}$; bond lengths around the $\left[\mathrm{Pt}(\mathrm{CN})_{2}\left(4,4^{\prime} \text {-dcbpy }\right)\right]^{2-}$ of $\mathbf{M g P t}-4 \cdot 9 \mathrm{H}_{2} \mathrm{O}$, CaPt-4.6 $\mathbf{H}_{2} \mathrm{O}$, and BaPt-4.5 $\mathrm{H}_{2} \mathrm{O}$; elemental analyses for $\mathbf{M g P t}-\mathbf{4} \cdot \mathbf{9} \mathrm{H}_{2} \mathrm{O}$ after grinding and exposure to $\mathrm{MeOH}$ vapour for 1 day. See DOI: 10.1039/b000000x/

301 (a) M. Hissler, J. E. McGarrah, W. B. Connick, D. K. Geiger, S. D. Cummings, R. Eisenberg, Coord. Chem. Rev. 2000, 208, 115-137. (b) M. Kato, Bull. Chem. Soc. Jpn. 2007, 80, 287-294. (c) K. M.-C. Wong, V. Y.-W. Yam, Coord. Chem. Rev. 2007, 251, 2477-2488. (d) I. Eryazici, C. N. Moorefield, G. R. Newkome, Chem. Rev. 2008, 108,

35 1834-1895. (e) J. A. GarethWilliams, S. Develay, D. L. Rochester, L. Murphy, Coord. Chem. Rev. 2008, 252, 2596-2611. (f) R. McGuire Jr., M. C. McGuire, D. R. McMillin, Coord. Chem. Rev. 2010, 254, 2574-2583.

2 (a) S. F. Rice, H. B. Gray, J. Am. Chem. Soc. 1983, 105, 4571-4575.

40 (b) S. D. Cummings, R. Eisenberg, J. Am. Chem. Soc. 1996, 118, 1949-1960. (c) W. B. Connick, H. B. Gray, J. Am. Chem. Soc. 1997, 119, 11620-11627. (d) V. W.-W. Yam. R. P.-L. Tang, K. M.-C. Wong, K.-K. Cheung, Organometallics 2001, 20, 4476-4482. (e) S. Huertas, M. Hissler, J. E. McGarrah, R. L. Lachicotte, R. Eisenberg,

45 Inorg. Chem. 2001, 40, 1183-1188. (f) V. W.-W. Yam, K. M.-C. Wong, N. Zhu, J. Am. Chem. Soc. 2002, 124, 6506-6507. (g) S.-W. Lai, H.-W. Lam, K.-K. Cheung, C.-M. Che, Organometallics 2002, 21, 226-234. (h) V. W.-W. Yam, K. H.-Y. Chan, K. M.-C. Wong, N. Zhu, Chem. Eur. J. 2005, 11, 4535-4543. (i) M. Kato, Y. Shishido, Y. Ishida, S. Kishi, Chem. Lett. 2008, 37, 16-17.

3 (a) C.-M. Che, L.-Y. He, C.-K. Poon, T. C. W. Mak, Inorg. Chem. 1989, 28, 3081-3083. (b) V. M. Miskowski, V. H. Houlding, Inorg. Chem. 1991, 30, 4446-4452. (c) J. A. Bailey, M. G. Hill, R. E. Marsh, V. M. Miskowski, W. P. Schaefer, H. B. Gray, Inorg. Chem. 1995,

55 34, 4591-4599. (d) W. B. Connick, L. M. Henling, R. E. Marsh, H. B. Gray, Inorg. Chem. 1996, 35, 6261-6265. (e) M. Kato, C. Kosuge, K. Morii, J. S. Ahn, H. Kitagawa, T. Mitani, M. Matsushita, T. Kato, S. Yano, M. Kimura, Inorg. Chem. 1999, 38, 1638-1641. (f) M. Kato, S. Kishi, Inorg. Chem. 2003, 42, 8728-8734.

604 (a) T. Koshiyama, A. Omura, M. Kato, M. Chem. Lett. 2004, 33, 1386-1387. (b) B. Ma, J. Li, P. I. Djurovich, M. Yousufuddin, R. Bau, M. E. Thompson, J. Am. Chem. Soc. 2005, 127, 28-29. (c) A. A. Rachford, F. N. Castellano, Inorg. Chem. 2009, 48, 10865-10867. (d)
R. Aoki, A. Kobayashi, H.-C. Chang, M. Kato, Bull. Chem. Soc. Jpn. $2011, \mathbf{8 4}, 218-225$

5 (a) C. L. Exstrom, J. E. Sowa Jr., C. A. Daws, D. Janzen, K. R. Mann, G. A. Moore, F. F. Stewart, Chem. Mater. 1995, 7, 15-17. (b) C. A. Daws, C. L. Exstrom, J. R. Sowa Jr., K. R. Mann, Chem. Mater. 1997, 9, 363-368. (c) C. E. Buss, C. E. Anderson, M. K. Pomije, C. M. Lutz, D. Britton, K. R. Mann, J. Am. Chem. Soc. 1998, 120, 7783-7790. (d) Y. Kunugi, K. R. Mann, L. L. Miller, C. L. Exstrom, J. Am. Chem. Soc. 1998, 120, 589-590. (e) Y. Kunugi, L. L. Miller, K. R. Mann, M. K. Pomije, Chem. Mater. 1998, 10, 1487- 1489.

6 (a) W. Lu, M. C. W. Chan, K.-K. Cheung, C.-M. Che, 75 Organometallics 2001, 20, 2477-2486. (b) S. M. Drew, D. E. Janzen, C. E. Buss, D. I. MacEwan, K. M. Dublin K. R. Mann, J. Am. Chem. Soc., 2001, 123, 8414-8415. (c) C. E. Buss, K. R. Mann, J. Am. Chem. Soc. 2002, 124, 1031-1039. (d) M. Kato, A. Omura, A. Toshikawa, S. Kishi, Y. Sugimoto, Angew. Chem. 2002, 114, 3315-3317; Angew.

80 Chem. Int. Ed. 2002, 41, 3183-3185. (e) S. Kishi, M. Kato, Mol. Cryst. Liq. Cryst., 2002, 379, 303-308. (f) W. Lu, M. C. W. Chan, N. Zhu, C.-M. Che, Z. He, K.-Y. Wong, Chem. Eur. J. 2003, 9, 61556166. (g) L. J. Grove, J. M. Rennekamp, H. Jude, W. B. Connick, J. Am. Chem. Soc. 2004, 126, 1594-1595. (h) M. Kato, S. Kishi, Y. 85 Wakamatsu, Y. Sugi, Y. Osamura, T. Koshiyama, M. Hasegawa, Chem. Lett. 2005, 34, 1368-1369. (i) S. C. F. Kui, S. S.-Y. Chui, C.M. Che, N. Zhu, J. Am. Chem. Soc. 2006, 128, 8297-8309. (j) P. Du, J. Schneider, W. W. Brennessel, R. Eisenberg, Inorg. Chem. 2008, 47, 69-77. (k) L. J. Grove, A. G. Oliver, J. A. Krause, W. B. Connick, Inorg. Chem. 2008, 47, 1408-1410. (1) J. Fornies, S. Fuertes, J. A. Lopez, A. Martin, V. Sicilia, Inorg. Chem. 2008, 47, 7166-7176. (m) M. L. Muro, C. A. Daws, F. N. Castellano, Chem. Commun. 2008, 6134-6136. (n) A. Kobayashi, Y. Fukuzawa, S. Noro, T. Nakamura, M. Kato, Chem. Lett. 2009, 38, 998-999. (o) J. Ni, Y.-H. Wu, X. 95 Zhang, B. Li, L.-Y. Zhang, Z.-N. Chen, Inorg. Chem. 2009, 48, 10202-10210. (p) A. Kobayashi, T. Yonemura, M. Kato, Eur. J. Inorg. Chem. 2010, 2465-2470. (r) J. S. Field, C. D. Grimmer, O. Q. Munro, B. P. Waldron, Dalton Trans. 2010, 39, 1558-1567. (s) Á Díez, J. Forniés, C. Larraz, E. Lalinde, J. A. López, A. Martín, M. T. Moreno, V. Sicilia, Inorg. Chem. 2010, 49, 3239-3251. (t) Y. Nishiuchi, A. Takayama, T. Suzuki, K. Shinozaki, Eur. J. Inorg. Chem. 2011, 11, 1815-1823. (u) Z. M. Hudson, C. Sun, K. J. Harris, B. E. G. Lucier, R. W. Schurko, S. Wang, Inorg. Chem. 2011, 50, 3447-3457.

1057 (a) H. Ito, T. Saito, N. Oshima, N. Kitamura, S. Ishizaka, Y. Hinatsu, M. Wakeshima, M. Kato, K. Tsuge, M. Sawamura, J. Am. Chem. Soc. 2008, 130, 10044-10045. (b) T. Abe, T. Itakura, N. Ikeda, K. Shinozaki, Dalton Trans. 2009, 711-715. (c) A. Laguna, T. Lasanta, J. M. López-de-Luzuriaga, M. Monge, P. Naumov, M. E. Olmos, J. Am. Chem. Soc. 2010, 132, 456-457. (d) J. Ni, X. Zhang, Y.-H. Wu, L.-Y. Zhang, Z.-N. Chen, Chem. Eur. J. 2011, 17, 1171-1183.

8 (a) A. Kobayashi, H. Hara, S. Noro, M. Kato, Dalton Trans. 2010, 39, 3400-3406. (b) H. Hara, A. Kobayashi, S. Noro, H.-C. Chang, M. Kato, Dalton Trans. 2011, 40, 8012-8018.

1159 (a) H. Li, M. Eddaoudi, M. O'Keeffe, O. M. Yaghi, Nature 1999, 402, 276-279. (b) M. Eddaoudi, D. B. Moler, H. Li, B. Chen, T. M. Reineke, M. O'Keeffe, O. M. Yaghi, Acc. Chem. Res. 2001, 34, 319 330. (c) N. L. Rosi, J. Kim. M. Eddaoudi, B. Chen, M. O'Keeffe, O. M. Yaghi, J. Am. Chem. Soc. 2005, 127, 1504-1518. (d) T. Louseau, 120 G. Férey, J. Fluor. Chem. 2007, 128, 413-422. (e) R. Banerjee, A. Phan. B. Wang, C. Knobler, H. Furukawa, M. O'Keeffe, O. M. Yaghi, Science 2008, 319, 939-943. (f) G. Férey, C. Serre, Chem. Soc. Rev. 2009, 38, 1380-1399. (g) D. J. Tranchemontagne, J. L. MendozaCortes, M. O'Keeffe, O. M. Yaghi, Chem. Soc. Rev. 2009, 38, 1257 1283.

10 (a) G. J. Halder, C. J. Kepert, B. Moubaraki, K. S. Murray, J. D. Cashion, Science 2002, 298, 1762-1765. (b) S. Kitagawa, R. Kitaura, S. Noro, Angew. Chem. Int. Ed. 2004, 43, 2334-2375. (c) R. Matsuda, R. Kitaura, S. Kitagawa, Y. Kubota, R. V. Belosludov, T. C. Kobayashi, H. Sakamoto, T. Chiba, M. Takata, Y. Kawazoe, Y. Mita, Nature 2005, 436, 238-241. (d) O. M. Yaghi, Nat. Mater. 2007, 6, 92-93. (e) B. D. Chandler, G. D. Enright, K. A. Udachin, S. Pawsey, J. A. Ripmeester, D. T. Cramb, G. K. H. Shimizu, Nat. Mater. 2008, 7, 229-235. (f) D. Tanaka, K. Nakagawa, M. Higuchi, S. Horike, Y. 
Kubota, T. C. Kobayashi, M. Takata, S. Kitagawa, Angew. Chem. Int. Ed. 2008, 47, 3914-3918. (g) J.-R. Li, R. J. Kuppler, H.-C. Zhou, Chem. Soc. Rev. 2009, 38, 1477-1504. (h) S. Horike, S. Shimomura, S. Kitagawa, Nat. Chem. 2009, 1, 695-704. (f) M. Higuchi, D.

5 Tanaka, S. Horike, H. Sakamoto, K. Nakamura, Y. Takashima, Y. Hijikata, N. Yanai, J. Kim, K. Kato, Y. Kubota, M. Takata, S. Kitagawa, J. Am. Chem. Soc. 2009, 131, 10336-10337. (i) T. Fukushima, S. Horike, Y. Inabushi, K. Nakagawa, Y. Kubota, M. Takata, S. Kitagawa, Angew. Chem. Int. Ed. 2010, 49, 4820-4824.

1011 (a) D.-Y. Hong, Y. K. Hwang, C. Serre, G. Férey, J.-S. Chang, Adv. Funct. Mater. 2009, 19, 1537-1552. (b) A. M. Shultz, O. K. Farha, J. T. Hupp, S. T. Nguyen, J. Am. Chem. Soc. 2009, 131, 4204-4205. (c) L. Yang, S. Kinoshita, T. Yamada, S. Kanda, H. Kitagawa, M. Tokunaga, T. Ishimoto, T. Ogura, R. Nagumo, A. Miyamoto, M.

15 Koyama, Angew. Chem. Int. Ed. 2010, 49, 5348-5351. (d) A. Dhakshinamoorthy, M. Alvaro, H. Garcia, Chem. Commun. 2010, 46, 6476-6478.

12 CrystalClear, Molecular Structure Corporation, Orem, UT, 2001.

13 SIR2004, M. C. Burla, R. Caliandro, M. Camalli, B. Carrozzini, G. L.

20 Cascarano, L. De Caro, C. Giacovazzo, G. Polidori, R. Spagana, J. Appl. Cryst. 2005, 38, 381-388.

14 SHLEX97, G. M. Sheldrick, Acta Crystallogr. Sect. A, 2008, 64, 112122.

15 A. L. Spek, J. Appl. Cryst. 2003, 36, 7-13.

2516 CrystalStructure 3.8, Crystal Structure Analysis Package, Rigaku and Rigaku/MSC (2000-2006), 9009 New Trails Dr, The Woodlands TX 77381 USA.

17 Md. K. Nazeeruddin, K. Kalyanasundaram, Inorg. Chem. 1989, 28, 4251-4259.

3018 These pictures were drawn by VESTA computer program. K. Momma, F. Izumi, J. Appl. Crystallogr. 2008, 41, 653-658. 